\title{
New insectivores (Lipotyphla, Mammalia) from the Late Miocene of the Sivas Basin, Central Anatolia
}

\author{
MARC FURIÓ, JAN VAN DAM \& FERHAT KAYA
}

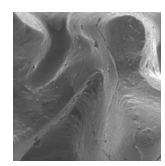

\begin{abstract}
The ages of the rich Central Anatolian Late Miocene mammal sites Hayranl1 1 and Düzyayla are only approximately known. One of the main reasons for the age uncertainties is the substantial faunal difference between Anatolia and Europe during this time slice, hampering correlations to the European MN system. Previously, a MN 10 or MN 11 age has been assigned to Hayranlı 1 (Anatolian Zone J) and a MN 12 age to Düzyayla (Zone K) based on rodents. Here we studied the fossil insectivores from these two Turkish Miocene localities. We found an almost identical faunal content of the two localities, including one erinaceid (Schizogalerix sinapensis), five soricids (Paenelimnoecus sp., Amblycoptus oligodon, Petenyia dubia, Soricinae indet. and Crocidurinae/Crocidosoricinae indet.), and two talpids (Desmanella aff. cingulata and Desmanodon larsi sp. nov.). With the only difference being the absence of Paenelimnoecus in Düzyayla, the insectivore fauna suggests that the sites are not significantly different in age. The presence of A. oligodon is indicative of MN 12 in Europe. The rest of the assemblage is in complete agreement with a Turolian (MN 11-13) age. Our results also imply that $D$. larsi sp. nov. represents the youngest record of Desmanodon, extending the biostratigraphical range of this genus significantly. - Key words: Hayranl, Düzyayla, Insectivora, Neogene, Turkey, Desmanodon, biostratigraphy.
\end{abstract}

FURIÓ, M., VAN DAM, J. \& KAYA, F. 2014. New insectivores (Lipotyphla, Mammalia) from the Late Miocene of the Sivas Basin, Central Anatolia. Bulletin of Geosciences 89(1), 163-181 (5 figures, 4 tables). Czech Geological Survey, Prague. ISSN 1214-1119. Manuscript received July 29, 2013; accepted in revised form October 24, 2013; published online January 21, 2014; issued January 21, 2014.

Marc Furió (corresponding author) \& Jan van Dam, Institut Català de Paleontologia Miquel Crusafont, Edifici ICP, Campus de la UAB (08193) Cerdanyola del Vallès, Barcelona, Spain; marc.furio@icp.cat, jan.vandam@icp.cat•Jan van Dam, Department of Earth Sciences, Utrecht University, Budapestlaan 4, 3584 CD, Utrecht, the Netherlands • Ferhat Kaya, Department of Geosciences and Geography, University of Helsinki, PO Box 64 (Gustaf Hällströmin katu 2a),00014 Helsinki, Finland; ferhat.kaya@helsinki.fi

Up to now, the correlation of early Late Miocene (MN 9-13) Anatolian micromammal assemblages to the MN scale is not straightforward, because of the low faunal similarity with the reference localities as defined in Spain for this interval, and the potential diachrony accompanying species dispersal. Whereas the interest for an independent Anatolian continental biostratigraphy started already in the 1960s (Sickenberg et al. 1975) the first approaches towards a modern Neogene biozonation appeared relatively recent (Ünay et al. 2003, De Bruijn et al. 2013). The 16 zones (A-P) used by these authors are based on associations of Muroidea and Dipodidae rodents from 42 localities and have a temporal resolution comparable to that of $\mathrm{MN}$ zones. Apart from biochronology, the number of magnetostratigraphic records and radiometric dates for mammal-containing sequences inAnatolia is still relatively low, with some notable exceptions (e.g., Kappelman et al. 2003).
The rich micromammal assemblages of Hayranlı 1 and Düzyayla (Sivas Basin, Central Anatolia, Fig. 1) are pivotal for the continental biochronology of the late Miocene of Anatolia. The rodent assemblage collected from the locality Hayranlı 1 has provisionally been correlated to MN 10 or MN 11, whereas Düzyayla has been correlated to MN 12 based on both micro- and macromammals (De Bruijn et al. 1999, 2013). Bovids from the area (Haliminhan1, the localities 58-HAY-14, 19, 23, and 70, situated in section roughly parallel to the one of Hayranli) have been assigned to MN 11 or "early" MN 12 (Bibi \& Güleç 2008), whereas a correlation of two Haliminhanı sites to MN 11 was made on the basis of the evolutionary stage of the suid Microstonyx major (58-HAY-2 and 19, Van der Made et al. 2013). Furthermore, unpublished work on the murines shows that one of the Hayranl1 1 Apodemus-Parapodemus populations is more primitive than the one from Düzyayla. On the other hand, in a recent study on the late Miocene Sciuridae from Anatolia 


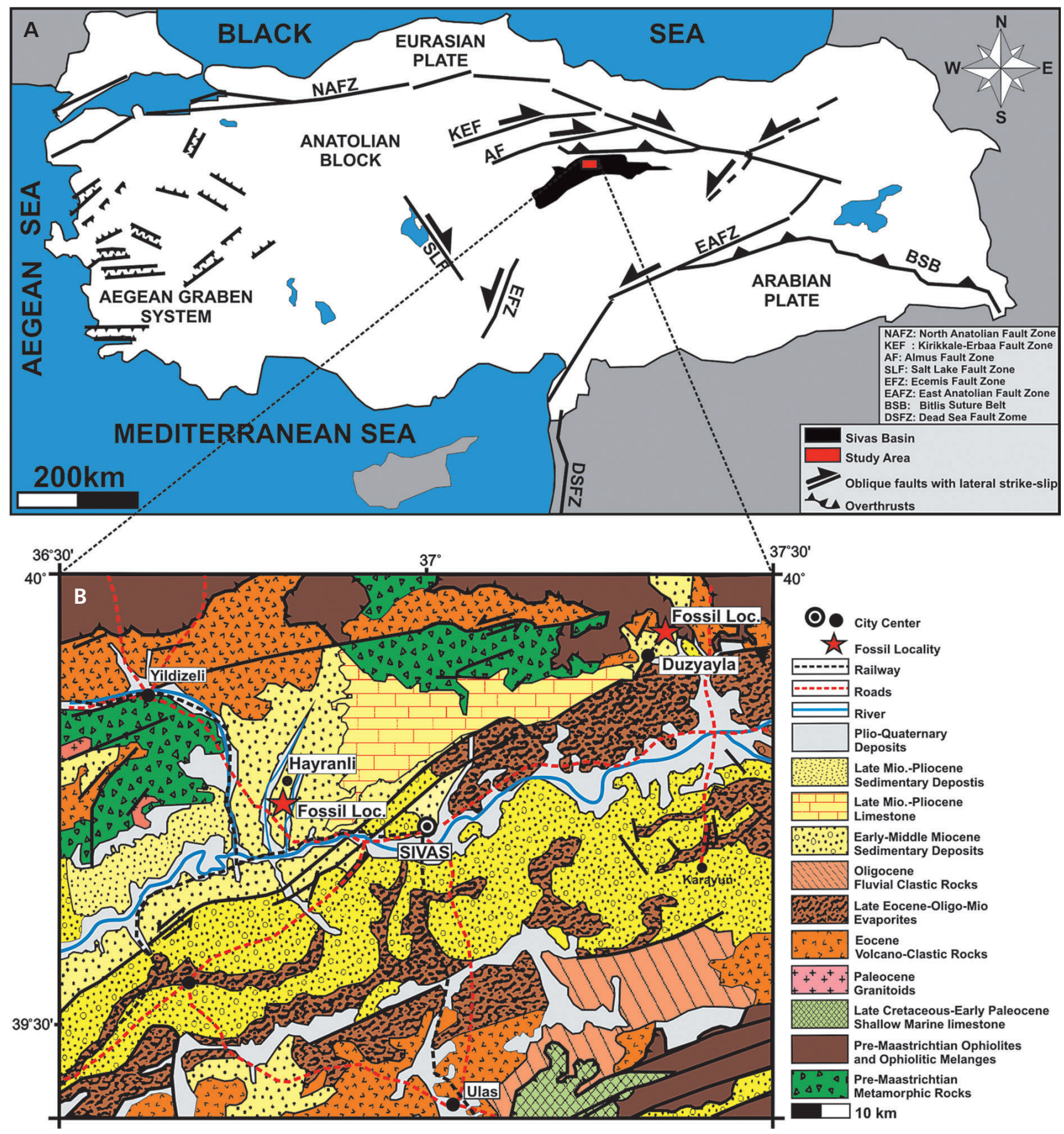

Figure 1. A - geodynamic divisions and distribution of major lineaments in Turkey (Gürsoy et al. 1997). • B - geologic map of the Sivas Basin showing fossil localities (Hayranlı 1 and Düzyayla) simplified from 1/500.000 scale geological map sheet of Directorate of Mineral Research and Exploration.

(Bosma et al. 2013), no differences in evolutionary stage could be observed between Spermophilinus bredai populations from both sites. In any case, based on murines and other rodents, it can be stated with certainty that Hayranl 1 and Düzyayla are younger than the series of localities contained in the Sinap Tepe composite section (11.0-9.3 Ma, MN 9-10; Kappelman et al. 2003).
Here we will focus on the insectivore assemblages from Hayranlı 1 and Düzyayla and several other time-equivalent sites from Anatolia and Greece. The systematics of the recovered Erinaceidae, Soricidae and Talpidae will be discussed, as well as the chronological implications. A complete chronological overview for the Hayranl 1 area including both bioand magnetostratigraphy will be published at a later stage. 


\section{Geological setting}

The deposits that include Hayranlı $1\left(39^{\circ} 44^{\prime} 34.40^{\prime \prime} \mathrm{N}\right.$, $36^{\circ} 48^{\prime} 43.30^{\prime \prime}$ E) and Düzyayla $\left(39^{\circ} 55^{\prime} 33.40^{\prime \prime} \mathrm{N}\right.$, $\left.37^{\circ} 18^{\prime} 56.50^{\prime \prime} \mathrm{E}\right)$ belong to the Sivas Basin in the eastern part of Central Anatolia. The formation of this complex basin is related to late Cretaceous-early Cenozoic extension following collision between the Pontide Orogene in the north and Tauride Orogene in the south (Gürsoy et al. 1997). From old to young, the Sivas Basin infill includes (Fig. 1): (1) Upper Cretaceous to Palaeogene marine sediments, volcanics, continental clastics, and lagoonal evaporates; (2) Early Neogene shallow marine and fluviatile deposits; and (3) Late Neogene and Quaternary fluviatile deposits (see Dirik et al. 1999 and references therein). Hayranlı 1 and Düzyayla belong to the third sequence (İncesu Formation), which was initiated at the end of the Middle Miocene by the collision and northward convergence of the Arabian Plate along the Bitlis-Zagros Suture Zone (Șengör \& Yilmaz 1981).

The Hayranli 1 small mammal collection was obtained from a green marl horizon between conglomerate and sandy red mudstone layers. The first small mammals were found by Gerçek Saraç (Mineral Research and Exploration institute of Turkey, MTA) and Tim White (University of California, Berkeley). In 1998, the collection was significantly enlarged by a Dutch-Turkish team directed by Hans de Bruijn (Utrecht University). In 2009, one of us (F.K.) continued sampling for small mammal fossils from Hayranl1 1 to expand on the previous findings (Kaya \& Kaymakçı 2013).

Around the same time, the Düzyayla micromammal material was recovered from two levels (clay and lignite) in the upper part of the İncesu Formation. The clay level has also provided fossils of macromammals, including abundant Deinotherium (see De Bruijn et al. 1999).

\section{Material and methods}

The main part of the studied insectivore material from Hayranl1 1 (abbreviated HAY1) will be stored in the Mineral Research and Exploration Institute of Turkey (MTA, Ankara). Further material from the same level collected by one of us (F.K.) in 2009, is housed in the Sivas Museum of Archaeology, for which the museum code (e.g., 58-HAY/84-INS-1) includes the province code of Sivas city (58), name of the succession (HAY refers Hayranl1), the locality number (84), the taxonomic group (INS refers insectivore) and the specimen number (1). The material from Düzyayla (abbreviated DÜ) will be stored at MTA also. Unlike the rodent material, the Düzyayla insectivore fossils from the clay and lignite level were not kept separate in the collection. Given the total amount of fossils of the two beds (De Bruijn et al. 1999) the bulk of the material can be assumed to have originated from the clay bed.

Measurements of the teeth follow Selänne (2003) for Schizogalerix, Reumer (1984) for Soricidae except Amblycoptus (Van Dam 2004), and García-Alix et al. (2011) for the talpids Desmanella and Desmanodon. The tribal classification of the Soricinae shrews follows Reumer (1998), whereas the generic distinction of species is according to Storch (1995) for the Blarinellini and Van Dam (2004) for the Anourosoricini. SEM photographs were taken at the Servei de Microscopia Electrònica from Universitat Autònoma de Barcelona.

Abbreviations. - a - lower antemolar; A - upper antemolar; AW - anterior width; BL - buccal length; C - upper canine; $\mathrm{H}$ - height; $\mathrm{i}$ - lower incisor; $\mathrm{I}$ - upper incisor; L - left (when referred to dental element), length (when referred to measurement); LL - lingual length; $\mathrm{L}_{\mathrm{m} 1-\mathrm{m} 3}$ - length of the lower molar row; LT - length of the talon; $\mathrm{m}$ - lower molar; $\mathrm{M}$ - upper molar; $\mathrm{p}$ - lower premolar; $\mathrm{P}$ - upper premolar; PE - posterior emargination; PW - posterior width; $\mathrm{R}$ - right; TAW - talonid width; TRW - trigonid width; $\mathrm{W}$ - width.

\section{Systematic palaeontology}

Order Lipotyphla Haeckel, 1866

Family Erinaceidae Fischer, 1814

Subfamily Galericinae Pomel, 1848

Tribe Galericini Pomel, 1848

\section{Genus Schizogalerix Engesser, 1980}

\section{Schizogalerix sinapensis Sen, 1990}

Figures 2A-F, 3B

Material from Hayranll 1. - 1 RP3, 1 RP4, 1 fragment of LM1, 1 Rm2 (fragmented), 1 trigonid of Lm1, 1 trigonid of Rm1, 1 trigonid of Rm2, 1 trigonid Rm3, 1 trigonid Lm3, 2 fragments of talonid of lower molars.

Description (Hayranll 1). - P3 (Fig. 2B) and P4 (Fig. 2A) are anteroposteriorly compressed. $\mathrm{P} 3(\mathrm{~L}=1.95 ; \mathrm{W}=1.85)$ smaller than $\mathrm{P} 4(\mathrm{~L}=2.27 ; \mathrm{W}=2.46)$. In the $\mathrm{P} 3$, the hypocone and the protocone are more or less conical elevations of similar size. In the P4 the protocone is higher and bigger than the hypocone, with both cusps having a crest-like shape, which is elongated in labiolingual direction. The crest posterior to the paracone of the $\mathrm{P} 4$ bears a small cuspule and a "V-shaped" notch anterior to it at halfway of its length. In the two posterolabial fragments of the upper molars, a connection of the posterior arm of the metaconule 
to the posterolabial corner interrupting the posterior cingulum is discernible.

The most distinctive trait in the lower molars is the posterior cingulid, which runs uninterruptedly from the bottom of the hypoconid to the lingual side, ending posteriorly to the entoconid (Fig. $2 \mathrm{C} ; \mathrm{W}=1.95$ ). In an unworn fragment of a talonid (Fig. 2E), the hypolophid is interrupted by the hypoconulid between the hypoconid and the entoconid. In the other two specimens available (Fig. 2C, $\mathrm{D} ; \mathrm{W}=2.11$ ), wear has resulted in a connection of this intermediate cuspule with the hypoconid. The entostylid is strongly reduced. The trigonids of the $\mathrm{m} 1$ and $\mathrm{m} 2$ are very narrow with the lingual opening of the basin being wider in the $\mathrm{m} 1$. Only a small notch separates the metaconid from the tiny paraconid in the $\mathrm{m} 2$. In the $\mathrm{m} 3$, the paraconid is curved and metaconid and protoconid are of similar size.

Material from Düzyayla. - 1 lingual fragment of RM1, 1 RM2, 1 lingual fragment of RM2.

Description (Düzyayla). - In the M2 (Fig. 3B), paracone, metacone and protocone are sharp and elevated. The metaconule is also high and sharp, and its posterior arm runs directly to the posteriolabial corner of the tooth, thus interrupting the posterior cingulum. The mesostyle is completely divided with its anterior part somewhat more branched than its posterior one. There is no cingulum covering the labial or lingual side of the tooth. The anterior cingulum runs from the parastyle to the anterior base of the protocone. The protoconule is a well-individualized cusp between the protocone and the paracone. The metaconule is disconnected from the endoloph in the three specimens, which all show a faint, double elevation at the position of the hypocone.

Remarks. - Anatolian representatives of Schizogalerix are known from the Early Miocene (De Bruijn et al. 2006) to the Late Miocene (Engesser 1980). The most simple representation of Schizogalerix from Anatolia involves a single evolutionary lineage including $S$. evae (MN 3), S. pasalarensis (MN 4-7), S. anatolica (MN 5-8), S. intermedia (MN 9), S. sinapensis (MN 10-11), and Schizogalerix sp. as recorded in Amasya (MN 12/13). Evolutionary trends include an increase of size, a progressive undulation and splitting of the mesostyle in M2, a reduction of the parastyle and labial cingula, and a narrowing of the paracone in the upper molars and the trigonid in the lower molars (Selänne 2003).

The material of Schizogalerix from Hayranlı 1 and Düzyayla is scanty. Nevertheless, an ascription to S. evae, $S$. pasalarensis, and $S$. anatolica can be ruled out given the absence of a connection between the hypoconid and the entoconid (the latter is connected to the posterior cingulum) in the lower molars. Furthermore, S. intermedia can be excluded as well, because the posterior cingulid of the lower molars is running parallel to the posterior arm of the hypoconid. In fact, the characters observed in both upper and lower teeth from the two localities clearly belong to "Morphotype 3" as recognized by Selänne (2003), with the upper molars from Düzyayla fitting perfectly the diagnosis of S. sinapensis by Sen (1990). The size of P3, P4 and M2 is around the lower limit of the ranges in the localities 8A and 120 (Sinap Formation, Selänne 2003). Also the narrow trigonids in $\mathrm{m} 1$ and $\mathrm{m} 2$ are indicative of S. sinapensis.

Outside Anatolia, S. sinapensis was included in the faunal list of the late Vallesian locality of Kastellios (K1, Crete, Greece; Van der Made 1996, Koufos 2006). However, our own inspection of the material from this locality (stored at Utrecht University) leads to another conclusion. Although the M2 of Schizogalerix from Düzyayla, Sinap 8A and Kastellios Hill are all of similar size (Fig. 3), the morphology of the material from Kastellios Hill is different from that of the other two sites. The degree of splitting of the mesostyle of the M2 from Kastellios Hill is stronger, and its anterior and posterior components do not display a "T-shape". The material from this Greek locality fits better the morphology of other Eastern Europe species like S. macedonica or S. zapfei / S. attica.

Family Soricidae Fischer, 1814

Subfamily Paenelimnoecinae Fejfar, Storch \& Tobien, 2006

\section{Genus Paenelimnoecus Baudelot, 1972}

\section{Paenelimnoecus sp.}

Figure 2G-I

Material from Hayranll 1. - 1 Lm1, 1 Rm1, 1 Rm2, 1 Ri1, 1 fragment of $\mathrm{L}$ hemimandible with part of $\mathrm{m} 2$, trigonid of an undetermined $\mathrm{Lm}$.

Description (Hayranll 1). - The i1 ( $\mathrm{L}=2.96)$ is monocuspulate and has a well-defined cingulid covering its base (Fig. 2I). The entoconid crests of the m1 (HAY1-802: $\mathrm{L}=1.09 ; \mathrm{TRW}=0.58 ; \mathrm{TAW}=0.62 ; 58 \mathrm{HAY} / 84-\mathrm{INS}-3$ : $\mathrm{L}=1.05 ; \mathrm{TRW}=0.63 ; \mathrm{TAW}=0.68)$ and the $\mathrm{m} 2$ are completely reduced. In the $\mathrm{m} 1$ (Fig. $2 \mathrm{H}$ ), the trigonid is moderately compressed labio-lingually. The $\mathrm{m} 1$ has its protoconid placed more anteriorly than the metaconid and has a curved protolophid. The oblique crest has a small notch at its anterior part. The $\mathrm{m} 2$ (58HAY/84-INS-2: TRW = 0.58; TAW $=0.61$ ) is similar to the $\mathrm{m} 1$, but it is a bit shorter. The condyle of the mandible (Fig. $2 \mathrm{G} 1 ; \mathrm{HC}=1.03 ; \mathrm{LLF}=1.08$; LUF $=0.55$ ) has a small and rounded upper facet and a broad lower facet. The width of the interarticular area is 


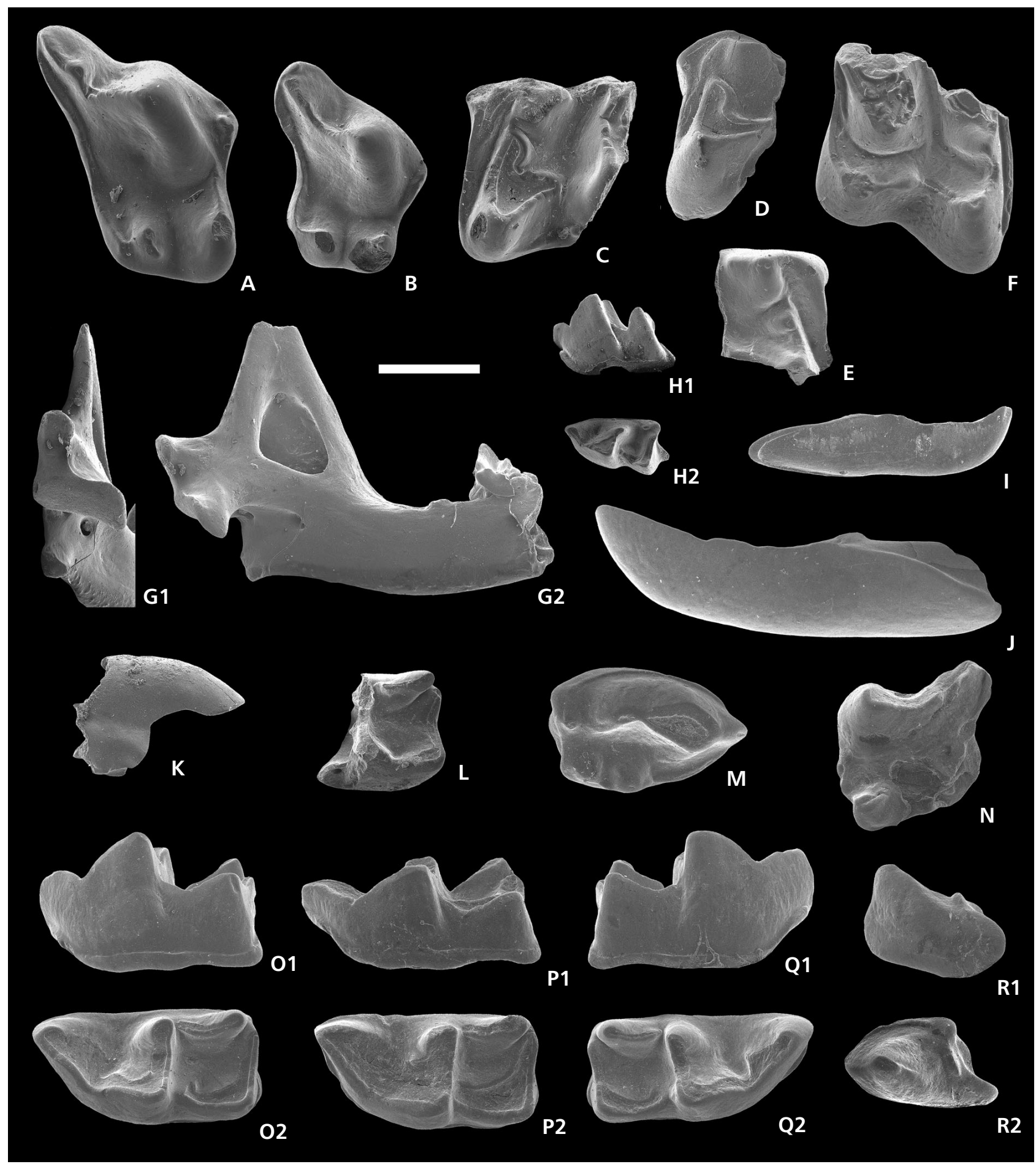

Figure 2. Schizogalerix sinapensis from Hayranl1 1 (A-E) and Düzyayla (F). A - HAY1-820 (right P4; occ. view); B - HAY1-821 (right P3; occ. view); C - HAY1-825 (talonid of right lower molar; occl. view); D - HAY1-826 (fragment of right lower molar; occl. view); E - HAY1-824 (posterolingual corner of left lower molar; occl. view); F - DÜ-1103 (lingual fragment of right M2; occl. view). • Paenelimnoecus sp. from Hayranl1 1 (G-I). G - HAY1-801 (left hemimandible with talonid of m2; 1 - post. view; 2 - ling. view); H - HAY1-802 (left m1; 1 - lab. view; 2 - occl. view); IHAY1-803 (right i1; lab. view). • Amblycoptus oligodon from Hayranl 1 (K, L) and Düzyayla (J; M-R). J - DÜ-1104 (left i1; lab. view); K - HAY1-806 (right I1; lab. view); L - HAY1-805 (talonid of left m1; occl. view); M - DÜ-1107 (right A1; occl. view); N - DÜ-1106 (left P4; occl. view); O - DÜ-1109 (left m1; 1 - lab. view; 2 - occl. view); P - DÜ-1108 (left m1; 1 - lab. view; 2 - occl. view); Q - DÜ-1110 (right m1; 1 - lab. view; 2 - occl. view); $\mathrm{R}$ - DÜ-1105 (left a1; 1 - lab. view; 2 - occl. view). Scale bar equals $1 \mathrm{~mm}$. 

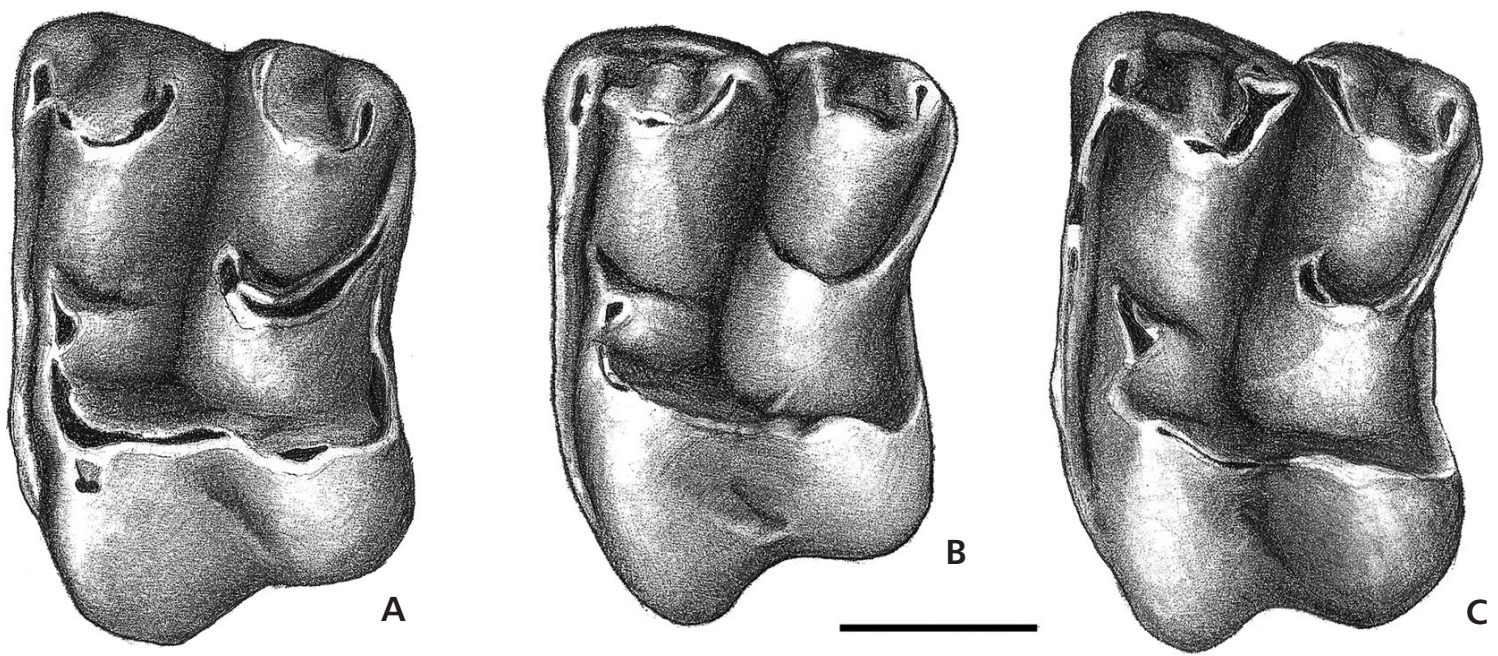

Figure 3. Upper M2 of Schizogalerix from A - Kastellios Hill, B - Düzyayla (DÜ-1101) and C - Sinap Tepe 8A. Scale bar equals 1 mm.

similar to that of the upper facet. The internal temporal fossa is rather small (Fig. 2G2).

Remarks. - The scarcity of the material makes a specific ascription difficult. Nevertheless, some small differences between Paenelimnoecus from Hayranl 1 and the other species of the genus can be observed. The material from Hayranl 1 is different from P. obtusus from Ertemte 2 (Storch 1995) in having a mandibular coronoid process not tilted anteriorly, in having a longer i1 and a somewhat narrower $\mathrm{m} 1$. The $\mathrm{m} 1$ from Hayranl 1 differs from P. chinensis from Yinan (Jin \& Kawamura 1997), P. repenningi from Kohfidisch (Bachmayer \& Wilson 1970), P. pannonicus from Osztramos 7 and 9 (Reumer 1984), Podlesice, Węże 1 and Rębielice Królewskie 1A (Rzebik-Kowalska 1990b) and Paenelimnoecus sp. 2 from Eskihisar (Engesser 1980) in having a somewhat smaller size. The $\mathrm{m} 1$ is similar in length but narrower than the ones of $P$. truyolsi from Valdemoros 6B, Villafeliche 4B, Vargas 7, Moratilla 2 and San Marco (Van den Hoek Ostende et al. 2009) and P. crouzeli from Sansan (Baudelot 1972, Engesser 2009). In addition, the species from Hayranl1 1 differs from $P$. crouzeli by its rather convex anterior margin of the ascending ramus (it is concave in $P$. crouzeli). Finally, the size of our $\mathrm{m} 1$ is similar to that of $P$. pannonicus from Csarnóta 2 (Reumer 1984), and, overall, Paenelimnoecus sp. 1 from Eskihisar (Engesser 1980), a form referable to P. crouzeli, according to Reumer (1984). Because of the lack of sufficient material we refrain from assigning the specimens to a named species.

Subfamily Soricinae Fischer, 1814

Tribe Anourosoricini Anderson, 1879

\section{Genus Amblycoptus Kormos, 1926}

\section{Amblycoptus oligodon Kormos, 1926}

Figure 2J-R

Material from Hayranlı 1. - 1 fragment of RI1, 1 fragment of Li1, 1 fragment of Lm1.

Description (Hayranl 1). - Judged by the fragment of I1 available (Fig. 2K), the dorsal margin is rather curved, the apex not fissident and the talon extremely reduced. The fragment of i1 lacks a buccal cingulid. The talonid of the m1 (Fig. 2L) shows a low hypoconid, and an entostylid, which is separated from the entoconid by a narrow and deep groove. The entoconid crest is prominent. The enamel in this fragment of molar shows a faint wrinkling.

Material from Düzyayla. - 1 Li1, 1 La1, 2 Lm1, 1Rm1, 1 RA1, 1 LP4.

Description (Düzyayla). - The i1 $(\mathrm{L}=5.33)$ is acuspulate, but there is a faint elevation in the middle of the buccal ridge (Fig. $2 \mathrm{~J})$. The a1 $(\mathrm{L}=1.72 ; \mathrm{W}=1.03)$ is longer on the labial side (Fig. 2R). Both sides have a high cingulid covering the base. A small posterior, transverse elevation is present, connecting both cingulids. In the three $\mathrm{m} 1$ recovered (Fig. 2O-Q; DÜ-1109: L = 2.52; W = 1.29; DÜ-1108: $\mathrm{L}=2.63 ; \mathrm{W}=1.39 ; \mathrm{DU}-1110 ; \mathrm{L}=2.53 ; \mathrm{W}=1.23$ ), the high and well-developed entoconid crests are separated from the much lower entostylids by a wide notch. The trigonid is elongated. A high cingulid covers the labial base of the crown.

The A1 (Fig. 2M; L $=2.25 ; \mathrm{W}=1.38$ ) has the typical molarized aspect of Amblycoptus (Reumer 1984, fig. 17) with a keel-shaped parastyle at the anterior edge of the tooth, a large paracone placed anteriorly, and a small metacone situated in the middle of the posterior margin. A small elevation connects paracone and metacone. Two 
Table 1. Ranges of length of different species of Amblycoptus and Crusafontina. *Presumed mistakes in the original publications which have been modified in the present work. In C. kormosi from Tardosbánya (Mészáros 1998) and Polgárdi 4 (Mészáros 1998, 1999) the lower limits of the ranges are 1.02 and 1.20 respectively. Both seem to be too low and they are likely typing errors, so the mean values have been considered the shortest reliable lengths. In A. oligodon from Polgárdi 2 (Mészáros 1999), the minimum length of the $\mathrm{m} 1 \mathrm{is} 1.87 \mathrm{~mm}$. This $\mathrm{m} 1$ would be too short for A. oligodon. Since there are only two specimens available, the maximum length is $2.85 \mathrm{~mm}$ and the mean is $2.75 \mathrm{~mm}$, the minimum length cannot be other than $2.65 \mathrm{~mm}$, which is a more reliable value.

\begin{tabular}{|c|c|c|c|c|c|}
\hline Site & $\mathrm{MN}$ & Species & m1 length & m2 length & Reference \\
\hline Zamkow Dolna & 16 & K. cf. topali & 3.14 & 1.74 & Rzebik-Kowalska (1975) \\
\hline Cave Mala & 14 & K. topali & 3.32 & 1.78 & Sulimski et al. (1979) \\
\hline Osztramos 1 & 14 & K. topali & $3.08-3.4$ & $1.56-1.75$ & Janossy (1972) \\
\hline Osztramos 1 & 14 & K. topali & 3.22 & 1.65 & Rzebik-Kowalska (1975) \\
\hline Osztramos 1 & 14 & K. topali & $3.17-3.56$ & $1.59-1.81$ & Reumer (1984) \\
\hline Kavurca & $13-14$ & cf. A. jessiae & 3.04 & - & Engesser (1980) \\
\hline Maramena & $13-14$ & A. jessiae & $2.67-3.27$ & $1.38-2.10$ & Doukas et al. (1995) \\
\hline Polgárdi 5 & 13 & K. topali & $2.60-3.50$ & - & Mészáros (1997) \\
\hline Can Vilella & 13 & A. jessiae & $2.88-2.99$ & 1.78 & Furió (2007) \\
\hline Romanyà d'Empordà & 13 & A. jessiae & $3.04-3.32$ & $1.66-1.90$ & Furió (2007) \\
\hline Las Casiones & 13 & A. jessiae & $2.74-3.39$ & $1.63-1.94$ & Van Dam (2004) \\
\hline Polgárdi 2 & 13 & A. oligodon & 3.33 & 1.90 & Kormos (1926) \\
\hline Polgárdi 2 & 13 & A. oligodon & $2.7-2.8$ & $1.7-1.9$ & Janossy (1972) \\
\hline Polgárdi 2 & 13 & A. oligodon & $2.65 *-2.85$ & - & Mészáros (1999) \\
\hline Polgárdi 4 & 13 & A. oligodon & $2.50-3.00$ & - & Mészáros (1999) \\
\hline Polgárdi 4 & 13 & C. kormosi & $2.50-3.20$ & $1.88 *-2.28$ & Mészáros $(1998,1999)$ \\
\hline Düzyayla & 12 & A. oligodon & $2.52-2.63$ & - & This work \\
\hline Tardosbánya & 12 & C. kormosi & $2.38-2.84$ & $1.76^{*}-2.00$ & Mészáros (1998) \\
\hline Kohfidisch & 11 & C. kormosi & $2.50-2.60$ & 1.80 & Bachmayer \& Wilson (1970) \\
\hline Frunzovka 2 & 11 & C. kormosi & $2.37-2.63$ & $1.62-1.77$ & Rzebik-Kowalska \& Nesin (2010) \\
\hline Sümeg & 10 & C. endemica & $2.39-2.72$ & $1.54-1.86$ & Mészáros $(1996,1998)$ \\
\hline Puente Minero 8 & 10 & C. endemica & 1.90 & - & Van Dam (2004) \\
\hline Puente Minero 2 & 10 & C. endemica & 1.99 & $1.61-1.69$ & Van Dam (2004) \\
\hline Masía del Barbo 2B & 10 & C. endemica & $2.08-2.20$ & $1.60-1.84$ & Gibert (1976) \\
\hline Masía del Barbo 2B & 10 & C. endemica & $2.01-2.11$ & $1.65-1.84$ & Van Dam (2004) \\
\hline Masía del Barbo 2A & 10 & C. endemica & $1.92-2.24$ & $1.60-1.68$ & Gibert (1976) \\
\hline Masía del Barbo 2A & 10 & C. endemica & $1.90-2.24$ & $1.54-1.90$ & Van Dam (2004) \\
\hline Rudabánya & 9 & C. endemica & $2.02-2.15$ & $1.70-1.91$ & Mészáros (1998), Ziegler (2005) \\
\hline Cascante 4 & 9 & C. endemica & 2.12 & - & Van Dam (2004) \\
\hline Can Llobateres & 9 & C. endemica & $2.00-2.12$ & $1.60-1.76$ & Gibert (1975) \\
\hline
\end{tabular}

small cusps (supposedly hypocone and protocone) are present on the lingual cingulum. The P4 (Fig. $2 \mathrm{~N} ; \mathrm{BL}=2.09$; $\mathrm{PE}=1.58 ; \mathrm{W}=1.66$ ) lacks its posterolingual corner and a tiny part of the anterior side. The lingual and the labial sides run almost parallel, giving the occlusal outline a sub-quadratic shape.

Remarks. - The material from Hayranlı 1 is in itself too scarce for a specific assignment. The talonid of the $\mathrm{m} 1$ is similar in width to the ones found in Düzyayla, with a similar development of the entoconid and the entostylid. In the latter locality, the size of all dental elements is below (or close to) the lowest values known in Amblycoptus (see Rzebik-Kowalska 1975, Sulimski et al. 1979, Doukas et al. 1995, Mészáros 1997, Van Dam 2004). Given the general size increase in some Anourosoricini during the latest Miocene (Van Dam 2004), our form could represent one of the oldest Amblycoptus, with a size close to that of its putative ancestor Crusafontina. Although its morphology clearly points to Amblycoptus, the measurements of the $\mathrm{m} 1$ fall within the range given for Crusafontina kormosi and C. endemica from Sümeg (Table 1). The primitive condition of this species of Amblycoptus is further supported by the morphology of the A1, in which the paracone is anteriorly placed, with the parastyle shaped as a projection of the anterior edge of the tooth. This condition is different to that found in the most derived forms of the clade such as Kordosia topali from Ozstramos 7 and 
Table 2. Measurements (in $\mathrm{mm}$ ) of dental and mandibular elements of Petenyia dubia from Düzyayla and Hayranlı 1.

\begin{tabular}{|c|c|c|c|c|c|c|}
\hline \multirow{2}{*}{$\begin{array}{l}\text { Petenyia dubia } \\
\text { Düzyayla }\end{array}$} & \multirow[t]{2}{*}{ Element } & \multicolumn{5}{|c|}{ Parameter } \\
\hline & & $\mathrm{L}$ & LT & $\mathrm{H}$ & & \\
\hline \multirow[t]{2}{*}{ DÜ-1137 } & I1 & 1.91 & 0.85 & 1.25 & & \\
\hline & & PE & LL & $\mathrm{BL}$ & AW & PW \\
\hline DÜ-1129 & M1 & 1.30 & 1.39 & 1.44 & 1.43 & 1.54 \\
\hline DÜ-1130 & M1 & 1.25 & - & 1.39 & 1.35 & - \\
\hline DÜ-1131 & M1 & 1.29 & - & 1.44 & 1.44 & - \\
\hline DÜ-1132 & M1 & 1.20 & 1.31 & 1.34 & 1.39 & 1.59 \\
\hline DÜ-1133 & M2 & 1.13 & 1.26 & 1.23 & 1.48 & 1.42 \\
\hline \multirow[t]{2}{*}{ DÜ-1134 } & M2 & 1.11 & 1.33 & 1.32 & 1.53 & 1.44 \\
\hline & & $\mathrm{L}$ & TRW & TAW & & \\
\hline DÜ-1114 & $\mathrm{m} 1$ & 1.42 & 0.79 & 0.85 & & \\
\hline DÜ-1115 & $\mathrm{m} 1$ & 1.41 & 0.77 & 0.87 & & \\
\hline DÜ-1116 & $\mathrm{m} 1$ & 1.39 & 0.72 & 0.85 & & \\
\hline DÜ-1117 & $\mathrm{m} 1$ & 1.38 & 0.74 & 0.84 & & \\
\hline DÜ-1120 & $\mathrm{m} 1$ & 1.41 & 0.85 & 0.90 & & \\
\hline DÜ-1121 & $\mathrm{m} 1$ & 1.46 & 0.80 & 0.89 & & \\
\hline DÜ-1118 & $\mathrm{m} 2$ & 1.25 & 0.75 & 0.82 & & \\
\hline DÜ-1119 & $\mathrm{m} 2$ & 1.26 & 0.73 & 0.74 & & \\
\hline DÜ-1122 & $\mathrm{m} 2$ & 1.38 & 0.79 & 0.81 & & \\
\hline DÜ-1123 & $\mathrm{m} 2$ & 1.30 & 0.76 & 0.81 & & \\
\hline DÜ-1124 & $\mathrm{m} 2$ & 1.30 & 0.80 & 0.83 & & \\
\hline DÜ-1125 & $\mathrm{m} 2$ & 1.35 & 0.84 & 0.88 & & \\
\hline DÜ-1126 & $\mathrm{m} 2$ & 1.31 & 0.83 & 0.80 & & \\
\hline DÜ-1127 & $\mathrm{m} 2$ & 1.35 & 0.83 & 0.86 & & \\
\hline DÜ-1128 & $\mathrm{m} 2$ & 1.28 & 0.73 & 0.75 & & \\
\hline Hayranlı 1 & & $\mathrm{PE}$ & LL & $\mathrm{BL}$ & AW & PW \\
\hline HAY1-809 & $\mathrm{P} 4$ & 1.09 & 1.09 & 1.50 & & 1.48 \\
\hline HAY1-810 & M2 & 1.10 & 1.23 & 1.28 & 1.58 & 1.41 \\
\hline HAY1-811 & M2 & 1.15 & 1.30 & 1.30 & 1.60 & 1.45 \\
\hline \multirow[t]{2}{*}{ HAY1-812 } & M2 & 1.28 & 1.33 & - & 1.54 & - \\
\hline & & $\mathrm{L}$ & TRW & TAW & & \\
\hline HAY1-814 & $\mathrm{m} 1$ & 1.54 & 0.83 & 0.90 & & \\
\hline HAY1-814 & $\mathrm{m} 2$ & 1.28 & 0.78 & 0.80 & & \\
\hline HAY1-813 & $\mathrm{m} 2$ & 1.37 & 0.80 & 0.80 & & \\
\hline HAY1-815 & $\mathrm{m} 2$ & 1.48 & 0.87 & 0.86 & & \\
\hline HAY1-816 & $\mathrm{m} 2$ & 1.47 & 0.80 & 0.87 & & \\
\hline \multirow[t]{2}{*}{ HAY1-817 } & $\mathrm{m} 2$ & 1.39 & 0.84 & 0.83 & & \\
\hline & & $\mathrm{L}$ & $\mathrm{W}$ & & & \\
\hline HAY1-814 & $\mathrm{m} 3$ & 1.02 & 0.63 & & & \\
\hline HAY1-813 & $\mathrm{m} 3$ & 1.09 & 0.58 & & & \\
\hline \multirow[t]{2}{*}{ HAY1-819 } & $\mathrm{m} 3$ & 1.18 & 0.73 & & & \\
\hline & & $\mathrm{Lm} 1-\mathrm{m}$ & & & & \\
\hline HAY1-814 & mand. & 3.68 & & & & \\
\hline
\end{tabular}

Polgárdi 5 (Reumer 1984, Mészáros 1997), in which the parastyle is clearly separated from the anterior ridge as an isolated elevation. Furthermore, there are two welldeveloped cusps on the lingual cingulum of the A1. This is, however, a less constant trait in some species, ranging from being very infrequent in A. jessiae from Maramena (Doukas et al. 1995) to almost always present in the same species from Spain (Van Dam 2004). Finally, the entoconid crest of the $\mathrm{m} 1$ is not fused with the hypolophid, leaving a wide separation between entoconid and entostylid. This condition definitely precludes an ascription to $A$. jessiae or K. topali, and resembles much closer that of A. oligodon, which is also similar in size to the material from Düzyayla.

Tribe Blarinellini Reumer, 1998

\section{Genus Petenyia Kormos, 1934}

Petenyia dubia Bachmayer \& Wilson, 1970 Figure 4A-J, Table 2

Material from Hayranlı 1. - 1 RP4, 1 RM1, 1 RM2, 1 LM2, 1R m1, $1 \mathrm{Rm} 2,1 \mathrm{Rm} 3,1$ fragment of $\mathrm{R}$ hemimandible with $\mathrm{m} 2,1$ fragment of $\mathrm{R}$ hemimandible with $\mathrm{m} 2$ and $\mathrm{m} 3,1$ fragment of left hemimandible with $\mathrm{m} 1, \mathrm{~m} 2$ and $\mathrm{m} 3$.

Description (Hayranl 1). - The P4 (Fig. 4C) has a rather straight posterior margin, without emargination. The protocone is small but clearly discernible; the hypocone is completely reduced. The parastyle protrudes considerably from the occlusal outline. In M1 and M2 (Fig. 4A, B) small posterior emarginations result in occlusal outlines not completely squared. The mesostyle is not divided and the endoloph is not continuous. In some cases the metaloph connects the protocone to the base of the metacone. The hypocone is reduced to an insignificant elevation of the lingual cingulum of the hypoconal flange.

In the lower molars, pigmentation affects the three upper quarters of the labial faces. In occlusal view, the presence of thick, basal cingulids in both $\mathrm{m} 1$ and $\mathrm{m} 2$ results in outlines that are subrectangular. The entoconid crests in $\mathrm{m} 1$ and $\mathrm{m} 2$ are stoutly built. In one $\mathrm{m} 1$, this crest is reduced to a blunt rounded cuspule (Fig. 4D2). The outline of the $\mathrm{m} 3$ is not rectangular despite a thick, basal cingulid. The talonid of the $\mathrm{m} 3$ is narrower than the trigonid, and the central talonid basin is reduced to a single-cusped crest (Fig. 4D2). The horizontal ramus shows a mental foramen placed below the oblique cristid of the m1 (Fig. 4D1).

Material from Düzyayla. - 2 RM1, 2 LM1, 1 RM2, 1 LM2, 2 Li1, 3 Lm1, 3 Rm1, 5 Rm2, 4 Lm2. 
Description (Düzyayla). - Only isolated elements have been recovered from this locality.

The I1 (Fig. 4I) is not fissident and has a rather pointed apex in lateral view. The talon is quite rounded and short. The root is a little bit shorter than the crown. The posterior emargination in the upper molars is reduced, resulting in a squarish occlusal outline. The most significant character in M1-2 (Fig. 4E, F) is the connection between the metaloph and the base of the metacone, closing the trigon valley posteriorly. The hypocone is reduced to a slight elevation of the lingual margin of the hypoconal flange or it is absent. The "W-shaped" ectoloph is asymmetric in M1 due to the elongated posterior crest, whereas it is symmetric in M2.

Two anterior fragments of lower incisors (Fig. 4J) show a straight posterior blade parallel to the ventral margin of the tooth, a rather pointed apex at the anterior tip of the tooth, and a lower intermediate cuspule slightly tilted forward. The m1 (Fig. 4H) have their trigonid valleys open lingually. The protolophid runs obliquely with respect to the lingual margin of the tooth with the metaconid placed more posteriorly than the protoconid. The talonid is wider and shorter than the trigonid. The entoconid crest is rather high and robust. The posterolingual notch separating entoconid and entostylid is deep. The cingulid surrounds the tooth crown completely, being thin at the posterior, labial and anterior side, and broad at the lingual side. The $\mathrm{m} 2$ (Fig. 4G) resemble the $\mathrm{m} 1$ except for the trigonid and talonid having a similar width, the occlusal outline being subrectangular and the protolophid running perpendicularly to the lingual margin of the tooth.

Remarks. - The soricid assemblages of both localities are dominated by this form. Judged from the reduced posterior emargination of P4/M1/M2, the subrectangular occlusal outline of $\mathrm{m} 1 / \mathrm{m} 2$, the short and high entoconid crest and the protruding but not fissident upper incisor, this species is attributable to the tribe Blarinellini or to the Soricini genus Zelceina (sensu Reumer 1998). Zelceina, Petenyia and Blarinella resemble each other in many respects (Reumer 1984), and some confusion has arisen on their definitions, with the same species having been allocated to different genera (Rzebik-Kowalska 1990a, Storch 1995). Here we use the diagnoses provided by Storch (1995) because it is the most updated and detailed work at the genus level. According to Storch's criteria, this "Blarinellini" material from Hayranlı 1 and Düzyayla does not belong to Alloblarinella because the endolophs of $\mathrm{M} 1$ and $\mathrm{M} 2$ are not continuous and the P4 has a well-developed protocone. An ascription to Paenepetenyia is precluded because of the uncontinuous endolophs and the weak posterior emargination. An ascription to the genus Zelceina would be supported by the presence of a non-fissident I1 with rather straight dorsal margin, the metalophs in M1 and M2 usually present, a reduced posterior emargination in P4, M1 and M2, a trapezoidal occlusal outline of the $\mathrm{P} 4$ with a protruding parastyle and "L-shaped" protocone, a bicuspulate i1 (with tendency to tricuspulate), a reduced talonid of $\mathrm{m} 3$ and a mental foramen under the reentrant valley of $\mathrm{m} 1$. On the other hand, our material does not fit the latter genus because its three known species (Z. soriculoides, Z. podlesicensis and Z. kormosi) have tethraedric hypocones (junction of three converging ridges at the hypoconal region in M1 and M2), low entoconid cristids on $\mathrm{m} 1$ and $\mathrm{m} 2$, and rather robust i1 (Rzebik-Kowalska 1990a, Storch 1995). The genus Blarinella, according to the descriptions of Storch (1995), is characterized by having a distinct valley between the postprotocrista and the hypoconal cingulum, and a tricupulate lower incisor. The present material differs in these two aspects, so we cannot attribute our material to Blarinella either. The morphologic traits fit best the description of the genus Petenyia: upper incisor with pointed apex, a parastyle on $\mathrm{P} 4$ conspicuously protruding anteriorly, upper molars (M1-2) with small but distinct metalophs, with rather large hypocones and hypoconal flanges, and lower molars (m1-2) with their entoconids close to the metaconids, rather high entoconid cristids and postentoconid notches wide and deep. The genus Petenyia includes three species: $P$. hungarica, $P$. katrinae and $P$. dubia. The ascription to $P$. katrinae is precluded by the absence of cingula around the bases of the protocones of M1/M2. P. hungarica differs from the presented material by a less developed protocone on its P4. In fact, most of the characters found in the Turkish material fit best the description of the original material of $P$. dubia from Kohfidisch (Bachmayer \& Wilson 1970), and the updated version provided by Reumer (1984) on the material from Osztramos 9. The only difference between the material from Turkey and that from the latter other localities is a slightly smaller size, which we consider to be within the range of intraspecific variation (less than 20 per cent difference in the lengths of $\mathrm{m} 1$ and $\mathrm{m} 2$ ).

Soricinae indet.

Figure 4K

Material from Hayranll 1. - 1 Lm1? (broken).

Description (Hayranlı 1). - The fragmentary lower molar (HAY1-808) is tentatively identified as an $\mathrm{m} 1$ because the talonid is wider than the trigonid. Size and aspect are different to any other soricid in the assemblage.

Material from Düzyayla. - 1 Rm1, 1 Lm1, 1 RM2, 1 L(M1)?.

Description (Düzyayla). - The trigonid of the $\mathrm{m} 1$ (DÜ-1111: L: 1.33; TRW: 0.64; TAW: 0.74; DÜ-1112: 
Table 3. Measurements (in mm) of dental elements of Desmanella aff. cingulata from Düzyayla and Hayranlı 1.

\begin{tabular}{|c|c|c|c|}
\hline \multirow{2}{*}{$\frac{\text { Desmanella aff. cingulata }}{\text { Düzyayla }}$} & \multirow[t]{2}{*}{ Element } & \multicolumn{2}{|c|}{ Parameter } \\
\hline & & $\mathrm{L}$ & W \\
\hline DÜ-1158 & M1 (R) & (+) 1.58 & (+) 1.58 \\
\hline DÜ-1159 & M1 (L) & 1.85 & 1.81 \\
\hline DÜ-1160 & M1 (R) & (+) 1.73 & (+) 1.60 \\
\hline DÜ-1161 & M2 (R) & (+) 1.25 & 1.61 \\
\hline DÜ-1162 & M2 (R) & (+) 1.44 & 1.71 \\
\hline DÜ-1163 & M2 (L) & (+) 1.39 & 1.71 \\
\hline DÜ-1164 & M2 (L) & 1.50 & 1.71 \\
\hline DÜ-1165 & M2 (R) & 1.48 & 1.63 \\
\hline DÜ-1168 & M3 (R) & 0.83 & 1.25 \\
\hline DÜ-1169 & M3 (L) & 0.90 & 1.29 \\
\hline DÜ-1170 & M3 (R) & 0.84 & 1.28 \\
\hline DÜ-1171 & M3 (L) & 0.95 & 1.41 \\
\hline DÜ-1172 & M3 (R) & 0.82 & - \\
\hline DÜ-1173 & M3 (L) & 0.96 & - \\
\hline DÜ-1174 & M3 (L) & 0.89 & 1.28 \\
\hline DÜ-1175 & M3 (L) & 0.82 & 1.29 \\
\hline DÜ-1176 & M3 (R) & 0.91 & 1.32 \\
\hline DÜ-1177 & M3 (L) & 0.93 & 1.30 \\
\hline DÜ-1178 & M3 (L) & 0.86 & 1.07 \\
\hline DÜ-1179 & M3 (R) & 0.94 & 1.33 \\
\hline DÜ-1180 & M3 (L) & 0.87 & 1.32 \\
\hline DÜ-1181 & M3 (R) & 0.88 & 1.35 \\
\hline DÜ-1155 & p4 (R) & 0.99 & 0.75 \\
\hline DÜ-1156 & p4 (L) & 0.82 & 0.65 \\
\hline DÜ-1157 & p4 (R) & 0.85 & 0.70 \\
\hline DÜ-1141 & m1 (R) & 1.41 & 1.07 \\
\hline DÜ-1142 & m1 (L) & 1.41 & 1.19 \\
\hline DÜ-1143 & m1 (L) & 1.60 & 1.28 \\
\hline DÜ-1144 & m1 (L) & - & - \\
\hline DÜ-1145 & m1 (L) & 1.44 & 1.10 \\
\hline DÜ-1146 & m1 (L) & 1.46 & 1.15 \\
\hline DÜ-1147 & m1 (L) & 1.44 & 1.06 \\
\hline DÜ-1148 & m1 (L) & 1.47 & 1.06 \\
\hline DÜ-1149 & m1 (R) & 1.41 & 1.16 \\
\hline DÜ-1150 & m1 (L) & 1.40 & 1.08 \\
\hline DÜ-1151 & m1 (L) & 1.52 & 1.18 \\
\hline DÜ-1152 & m1 (L) & 1.38 & 1.17 \\
\hline DÜ-1153 & m1 (R) & 1.42 & 1.08 \\
\hline DÜ-1140 & $\mathrm{m} 2(\mathrm{R})$ & 1.56 & 1.18 \\
\hline DÜ-1166 & $\mathrm{m} 2(\mathrm{R})$ & 1.48 & 0.93 \\
\hline DÜ-1167 & $\mathrm{m} 2(\mathrm{R})$ & 1.55 & 1.10 \\
\hline DÜ-1182 & m3 (L) & 1.21 & 0.81 \\
\hline DÜ-1183 & m3 (R) & 1.18 & 0.73 \\
\hline DÜ-1184 & m3 (L) & 1.14 & 0.73 \\
\hline DÜ-1185 & m3 (R) & 1.18 & 0.75 \\
\hline DÜ-1186 & m3 (L) & 1.12 & 0.73 \\
\hline
\end{tabular}

\begin{tabular}{llcl}
\hline Desmanella aff. cingulata & Element & \multicolumn{2}{c}{ Parameter } \\
\hline Düzyayla & & $\mathrm{L}$ & $\mathrm{W}$ \\
\hline DÜ-1187 & $\mathrm{m} 3(\mathrm{~L})$ & 1.09 & 0.70 \\
DÜ-1188 & $\mathrm{m} 3(\mathrm{~L})$ & 1.18 & 0.72 \\
DÜ-1189 & $\mathrm{m} 3(\mathrm{~L})$ & 1.21 & 0.84 \\
DÜ-1190 & $\mathrm{m} 3(\mathrm{R})$ & 1.32 & 0.90 \\
DÜ-1191 & $\mathrm{m} 3(\mathrm{R})$ & 1.21 & 0.83 \\
DÜ-1192 & $\mathrm{m} 3(\mathrm{~L})$ & 1.19 & 0.87 \\
DÜ-1193 & $\mathrm{m} 3(\mathrm{~L})$ & 1.20 & 0.80 \\
DÜ-1194 & $\mathrm{m} 3(\mathrm{~L})$ & 1.18 & 0.77 \\
DÜ-1195 & $\mathrm{m} 3(\mathrm{R})$ & 1.27 & 0.83 \\
\hline Hayranl1 1 & & $\mathrm{~L}$ & $\mathrm{~W}$ \\
\hline HAY1-834 & $\mathrm{M} 1(\mathrm{R})$ & $(+) 1.72$ & 1.78 \\
HAY1-835 & $\mathrm{M} 1(\mathrm{R})$ & $(+) 1.54$ & 1.58 \\
HAY1-836 & $\mathrm{M} 2(\mathrm{~L})$ & $(+) 1.69$ & 1.81 \\
HAY1-838 & $\mathrm{M} 3(\mathrm{R})$ & 0.90 & 1.31 \\
HAY1-839 & $\mathrm{m} 1(\mathrm{R})$ & 1.55 & 1.29 \\
HAY1-840 & $\mathrm{m} 1(\mathrm{~L})$ & 1.51 & 1.14 \\
HAY1-841 & $\mathrm{m} 1(\mathrm{~L})$ & 1.41 & 1.19 \\
HAY1-842 & $\mathrm{m} 2(\mathrm{~L})$ & 1.78 & 1.16 \\
HAY1-843 & $\mathrm{m} 2(\mathrm{~L})$ & - & 1.20 \\
HAY1-844 & $\mathrm{m} 3(\mathrm{R})$ & 1.27 & 0.87 \\
HAY1-845 & $\mathrm{m} 3(\mathrm{R})$ & 1.32 & 0.80 \\
HAY1-846 & $\mathrm{m} 3(\mathrm{R})$ & 1.28 & $(+)$ \\
58HAY/84-INS-4 & $\mathrm{m} 3(\mathrm{R})$ & -68 \\
\hline & & & 0.78 \\
\hline
\end{tabular}

L: 1.34; TRW: 0.65; TAW: 0.75) is widely open lingually, with the metaconid placed more posteriorly than the protoconid. The reentrant valley is rather pronounced. A thin basal cingulid covers the labial and the posterior border. The entoconid crest is quite thin and high.

In the M2 (Fig. 4K; DÜ-1136: PE: 1.03; LL: 1.26; BL: 1.20; AW: 1.40 ; PW: 1.38), the posterior emargination is very pronounced. The mesostyle occupies a less labial position than the parastyle and the metastyle. The posterior arm of the protocone neither connects with the base of the metacone by means of a metaloph, nor with the hypocone. The hypocone is a simple elongated elevation at the lingual end of the hypoconal flange. A posterior cingulum runs from hypocone to metastyle. A fragment of a M1 (DÜ-1135; PE: 1.08; BL: 1.30; AW: 1.46) is also tentatively ascribed to this form because there is no metaloph connecting the protocone with the base of the metacone and because the posterior emargination is rather pronounced.

Remarks. - This infrequent species in the assemblages from Hayranl 1 and Düzyayla does not correspond to any of the other soricids found. It is larger than Paenelimnoecus, smaller than Amblycoptus, and it has a more pronounced 


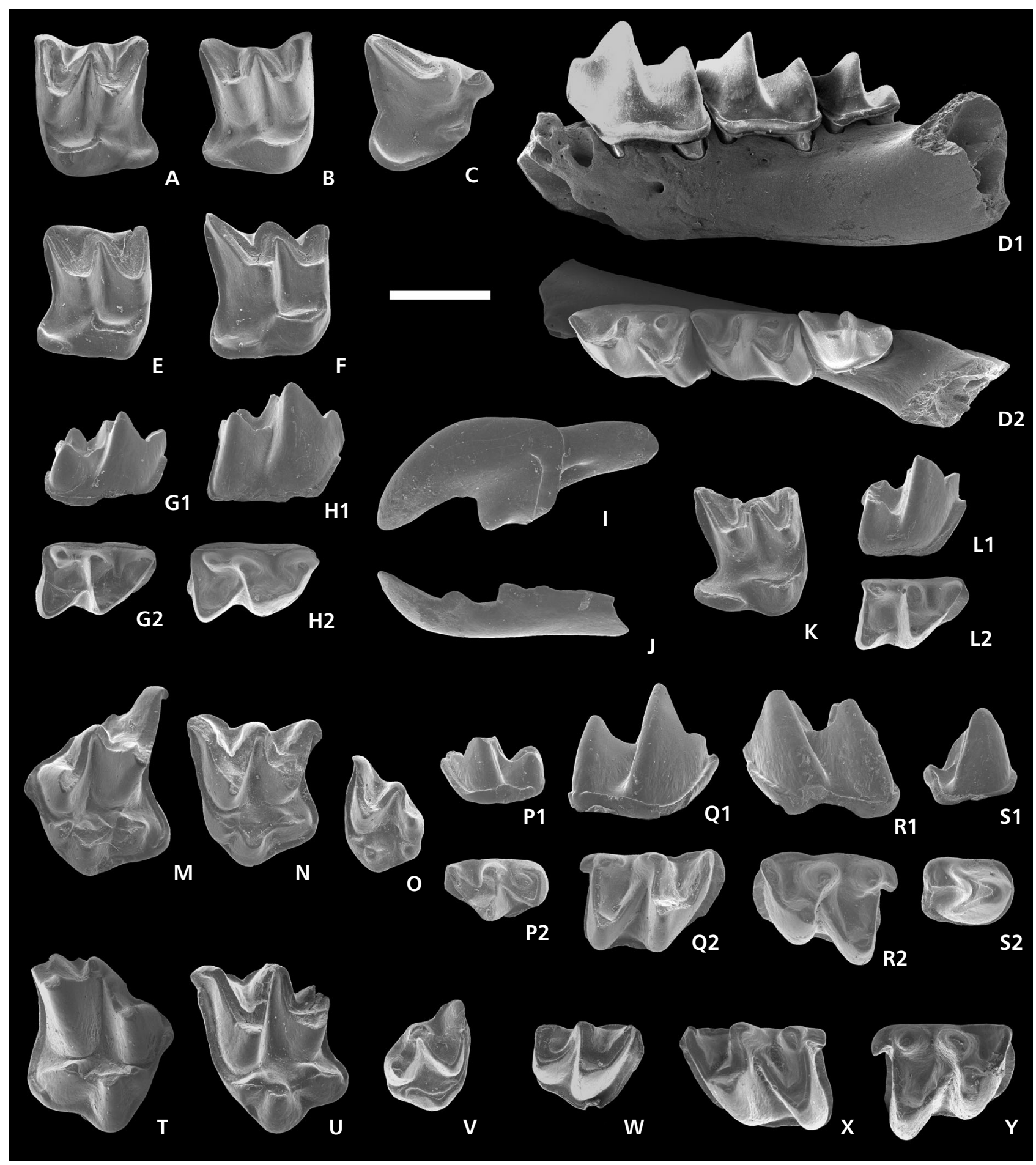

Figure 4. Petenyia dubia from Hayranlı 1 (A-D) and Düzyayla (E-J). A - HAY1-810 (left M2; occl. view); B - HAY1-811 (right M2; occl. view); C-HAY1-809 (right P4; occl. view); D - HAY1-814 (left horizontal ramus with m1-m3 series; 1 - lab. view; 2 - occl. view); E - DÜ-1132 (right M2; occl. view); F - DÜ-1132 (right M1; occl. view); G - DÜ-1118 (right m2; 1 - lab. view; 2 - occl. view); H - DÜ-1115 (right m1; 1 - lab. view; 2 - occl. view); I - DÜ-1137 (left I1; lab. view); J - DÜ-1118 (left i1; lab. view). $\bullet \mathrm{K}$ - Soricinae indet. from Düzyayla. DÜ-1136 (right M2; occl. view). $\bullet$ L - Crocidurinae aut Crocidosoricinae indet. from Düzyayla. DÜ-1113 (right m2; 1 - lab. view; 2 - occl. view). $\bullet$ M-Y - Desmanella aff. cingulata from Düzyayla (M-S) and Hayranl1 1 (T-Y). M - DÜ-1159 (left M1; occl. view); N-DÜ-1164 (left M2; occl. view); O-DÜ-1169 (left M3; occl. view); P-DÜ-1187 (left m3; 1 - lab. view; 2 - occl. view); Q - DÜ-1167 (right m2; 1 - lab. view; 2 - occl. view); R - DÜ-1151 (left m1; 1 - lab. view; 2 - occl. view); S - DÜ-1155 (right p4; 1 - lab. view; 2 - occl. view); T - HAY1-835 (right M1; occl. view); U - HAY1-836 (left M2; occl. view); V - HAY1-838 (right M3; occl. view); W - HAY1-844 (right m3; occl. view); X - HAY1-842 (left m2; occl. view); Y - HAY1-839 (right m1; occl. view). Scale bar equals 1 mm. 
posterior emargination in upper molars and shorter talonids than Petenyia. Moreover, upper and lower molars do not have the typical mesio-distally compressed aspect of crocidurines or crocidosoricines. The sample is, however, too scarce to identify the material even at the genus level. The occlusal outline and the hypocone morphology of the upper molars are Sorex-like, but the lower molars seem too narrow. In the absence of more elements and diagnostic characters, we prefer to leave the identification of this material as Soricinae indet.

Subfamily Crocidurinae Milne-Edwards, 1872 aut Subfamily Crocidosoricinae Reumer, 1987 Crocidurinae aut Crocidosoricinae indet. Figure 4L

Material from Hayranl 1. - $1 \mathrm{Lm} 2$.

Description (Hayranll 1). - The m2 (HAY1-807; L: 1.29; TRW: 0.78; TAW: 0.75) has a short talonid. The lingual opening of the trigonid is acute, because metaconid and protoconid run perpendicularly with regard to the lingual margin. The basal cingulid is most pronounced under the paralophid.

Material from Düzyayla. - 1 Rm2 (Fig. 4L).

Description (Düzyayla). - The m2 (DÜ-1113: L: 1.22; TRW: 0.72; TAW: 0.76) from this locality has exactly the same morphology as the one from Hayranl 1.

Remarks. - The short talonid of the lower molars suggests their ascription to the subfamilies Crocidurinae or Crocidosoricinae sensu Furió et al. (2007). Further material is needed for a more precise identification.

Family Talpidae Fischer, 1814

Subfamily Uropsilinae Dobson, 1883

\section{Genus Desmanella Engesser, 1972}

\section{Desmanella aff. cingulata Engesser, 1980}

Figure 4M-Y, Table 3

Material from Hayranl 1. - 2 RM1, 1 LM2, 1 RM3, 1 Rm1, 2 Lm1, 1 Lm2, 1 talonid Lm2, 4 Rm3, 2 anterior elements.

Description from Hayranl 1. - The M1 show a posterior cingulum reaching the base of the paracone lingually in HAY1-834, but already vanishing below the metaconule in HAY1-835 (Fig. 4T) ("metaconule" concept sensu García-Alix et al. 2011, and references therein). In one spe- cimen the mesostyle is not completely divided, whereas in the other one it splits into two small elevations. The accessory cusp in M1-2 is not pronounced. In the only M2 with the lingual part preserved (HAY1-836), a strong cingulum covers the anterior border between the protoconule and the base of the parastyle (Fig. 4U), whereas the posterior cingulum connects lingually to the metaconule. Also in the M3 (Fig. 4V), the anterior cingulum connects to the protoconule. The metaconule of the M3 is a tiny cusp placed directly lingual of the base of the metacone, at the cost of the development of a posterior cingulum.

The three lower molars (Fig. 4W-Y) display continuous labial cingulids. In m1 (Fig. 4Y) and m2 (Fig. 4X), these run uninterruptedly from the base of the paraconid to the entostylid. In $\mathrm{m} 3$ (Fig. $4 \mathrm{~W}$ ), it ends just below the hypoconid. The oblique cristid ends at a position intermediate between protoconid and metaconid, i.e., relatively far from the lingual side. The $\mathrm{m} 3$ has a well-developed talonid basin, which is open to the lingual side.

Material from Düzyayla. - 2 RM1, 1 LM1, 3 RM2, 2 LM2, 6 RM3, 8 LM3, 2 Rp4, 1 Lp4, 3 Rm1, 10 Lm1, 3 Rm2, $5 \mathrm{Rm} 3,9 \mathrm{Lm} 3$.

Description (Düzyayla). - The material is very similar to that of Hayranl1 1. Unlike Hayranlı 1, Düzyayla has yielded p4s (Fig. 4S). These are rather small (Table 3). Their occlusal outline is rather oval, with the posterior margin relatively straight (Fig. 4S2). In the only unworn specimen, the main cusp bears two posterior crests directed to the posterolingual and posterolabial edges, respectively. There is a small elevation pointing to the middle of the posterior margin.

In one M1 (DÜ-1158), the posterior cingulum reaches the base of the protocone, whereas in the other two specimens, it ends at the base of the metaconule. The latter condition is more evident in the M2, in which the posterior cingula end at the posterolingual edge of the tooth in four out of the five specimens. In one of these (DÜ-1164), a thin lingual cingulum reaches the posterior base of the protocone. The mesostyle is not divided in any of the M1 or M2 in which this structural element is preserved.

Remarks. - The presence of Desmanella in Düzyayla had been previously reported by De Bruijn et al. (1999, fig. 6) under the generic name "Permenella", which is evidently a typing error (Van den Hoek Ostende, pers. comm.). From the point of view of size, the Desmanella from Hayranlı 1 and Düzyayla is too small to be classified as D. amasyae. On the other hand, it is equally sized as the two other Turkish species D. sickenbergi and D. cingulata (Engesser 1980, figs 35-37). The most important characters to discern the former from the latter of these two species are a P4 with more compact aspect, M1-2 that are less squared 
(i.e., with a posteriorly extended lingual part) (Engesser 1980, figs 31, 43) with a protocone less protruding and a posterolingual cingulum running less anteriorly, m1-2 with their buccal cingulids less continuous (Engesser 1980, fig. 32) and oblique cristids meeting the metaconid at a more lingual position. In our samples no $\mathrm{P} 4$ was recovered, and the characters specified for M1-2 do not help identifying our material with complete certainty. We do not find differences between the protocones of M1-2 of our assemblages and those of $D$. sickenbergi and $D$. cingulata, and the posterior cingula in our material are variable. In most specimens from Düzyayla the posterolingual extension of the cingula in M1 and M2 closely resembles that of D. sickenbergi from Eskihisar. Nonetheless, the $\mathrm{m} 1$ and m2 mostly show continuous labial cingulids all around their labial bases unlike in D. sickenbergi, and the oblique cristids in $\mathrm{m} 1 \mathrm{~s}$ attach less far lingually from the metaconid than in D. sickenbergi. Thus, the features of our samples fit best the description of $D$. cingulata, although the match is not perfect.

Talpidae inc. sed.

\section{Genus Desmanodon Engesser, 1980}

\section{Desmanodon larsi sp. nov.}

Figure 5, Table 4

Holotype. - HAY1-854 (Lm2).

Paratypes. - HAY1-852 (1 LM3), HAY1-849 (LM1), HAY1-853 (Lp4), HAY1-856 (Rm1), HAY1-855 (Lm2).

Type locality. - Hayranlı 1.

Etymology. - In honor of Lars W. van den Hoek Ostende, one of the leading specialists in Eurasian fossil insectivores, who thoroughly reviewed the genus Desmanodon and authored three new species of this genus.

Diagnosis. - Large species of Desmanodon with rather stout cheek teeth. Lower molars lacking any trace of a labial or lingual cingulid. No entoconid crests in $\mathrm{m} 1$ and $\mathrm{m} 2$. Mesostyle in upper molars weakly divided.

Differential diagnosis. - Desmanodon larsi differs from all other Desmanodon species by its large size, except from $D$. major. It differs from the latter species by the presence of a parastyle in the $\mathrm{P} 4$ and by the complete absence of labial cingulids in the lower molars. Furthermore, it differs from $D$. minor by having more robust molars and by the presence of a small parastyle in the P4. It differs from $D$. crocheti and D. burkarti by the shape of the mesostyle,
Table 4. Measurements (in $\mathrm{mm}$ ) of dental elements of Desmanodon larsi sp. nov. from Düzyayla and Hayranlı 1.

\begin{tabular}{|c|c|c|c|}
\hline \multirow{2}{*}{$\frac{\text { Desmanodon larsi sp. nov. }}{\text { Düzyayla }}$} & \multirow[t]{2}{*}{ Element } & \multicolumn{2}{|c|}{ Parameter } \\
\hline & & $\mathrm{L}$ & W \\
\hline DÜ-1201 & P3 (R) & 1.26 & - \\
\hline DÜ-1200 & P4 (R) & 1.93 & 1.51 \\
\hline DÜ-1198 & M3 (R) & 1.21 & 1.76 \\
\hline DÜ-1199 & M3 (R) & 1.31 & 1.69 \\
\hline DÜ-1154 & m1 (R) & 2.30 & 1.66 \\
\hline DÜ-1196 & m3 (L) & 1.73 & 1.11 \\
\hline DÜ-1197 & $\mathrm{m}(\mathrm{R})$ & - & (+) 1.24 \\
\hline Hayranlı 1 & & $\mathrm{~L}$ & $\mathrm{~W}$ \\
\hline HAY1-849 & M1 (L) & 2.74 & 2.49 \\
\hline HAY $1-850$ & M1 (L) & (+) 2.28 & 2.13 \\
\hline HAY1-851 & M3 (R) & 1.45 & 2.22 \\
\hline HAY1-852 & M3 (L) & 1.38 & 1.93 \\
\hline HAY1-853 & $\mathrm{p} 4(\mathrm{~L})$ & 1.41 & 0.75 \\
\hline HAY1-856 & m1 (R) & 2.06 & 1.44 \\
\hline HAY1-854 & m2 (R) & 2.31 & 1.38 \\
\hline HAY1-855 & $\mathrm{m} 2(\mathrm{~L})$ & 2.40 & 1.45 \\
\hline HAY1-857 & $\mathrm{m} 2(\mathrm{~L})$ & 2.27 & 1.48 \\
\hline
\end{tabular}

which is slightly divided in the upper molars, and by a wider talonid with respect to its trigonid in the $\mathrm{m} 1$. It differs from D. ziegleri by not having well-defined protoconules and metaconules in M1 and M2 and by having stouter teeth. It differs from $D$. antiquus and D. fluegeli by the absence of an anterolabial cingulid, which is reduced to a somewhat protruding parastylid, and by less divided mesostyles in its upper molars. It differs from $D$. daamsi in the absence of entoconid cristids.

Material from Hayranlı 1. - 1 RM3, 1 LM3, 2 LM1, 1Lp4, 1 Rm1, 1 Rm2, 2 Lm2, 1 LC.

Description (Hayranll 1). - The upper canine (Fig. 5F) is double rooted. In lateral view, the anterior margin is convex and the posterior side is concave. There is a vertical deep groove at the anterolingual part of the tooth. In M1 the protocone is the only clearly discernible lingual cusp (Fig. 5G, H). A continuous, small anterior ridge connects the protocone with the parastyle. The posterior arm of the protocone ends posteriorly of the base of the metacone. The parastyle protrudes notably from the occlusal outline. The mesostyle in M1 and M3 is faintly divided by a small notch. The M3 has a subtriangular outline (Fig. 5I, J). The anterior arm of the protocone of M3 ends anteriorly to the base of the paracone and the posterior arm extends to the base of the metacone, from which it is separated by a small notch.

The p4 (Fig. 5N) is double rooted and the crown is laterally compressed. The main cusp bears a faint, descending 
posterolingual crest. A small cingulid covers the base of the anterior keel of the tooth. The posterolabial zone is a concave surface. The lower molars (Fig. 5K-M) have no metacristid and their talonid basins are anterolingually open. The oblique cristid ends at the center of the posterior face of the trigonid in the $\mathrm{m} 1$, and slightly more lingually in the $\mathrm{m} 2$. There is no labial or lingual cingulid in $\mathrm{m} 1$ and $\mathrm{m} 2$. The entostylid protrudes notably from the occlusal outline of $\mathrm{m} 1$ and $\mathrm{m} 2$, whereas the parastylid does so only in $\mathrm{m} 2$.

Material from Düzyayla. - $1 \mathrm{Rm} 1,1$ trigonid Rm2, 1Lm3, 1 RP3, 1 RP4, 2 RM3.

Description (Düzyayla). - A buccal fragment was recovered (Fig. 5C), which we attribute to P3. The main cusp is preserved as well as the undulating posterior crest, which is similarly shaped as in P4. The preserved part bears a continuous, thin cingulum. The P4 (Fig. 5B) has a convex labial margin, a rather straight anterolingual border and a concave posterolingual part in occlusal view. Overall, P4 corresponds to "morphotype A" proposed by Van den Hoek Ostende (1997, fig. 2) because the protocone is conical and the parastyle is small. The paracone is high and it bears an undulated and sharp posterior crest that is connected to a narrow posterolingual cingulum. A thin cingulum is present at the posterolabial base. The two M3 (Fig. 5A) are considerably worn. They are similar to the ones from Hayranl1 1 , with a metaconule separated from the base of the metacone by a deep notch and with the anterior arm of the protocone not connected to the base of the paracone. They differ from the Hayranl1 1 specimens in other aspects such as the somewhat concave posterolingual margin (occlusal view, rather straight in Hayranlı 1, Fig. 5I, J), the strongly separated mesostyle as visible in the least worn specimen, and the mesiodistal compression.

The lower elements are rather similar to those from Hayranl1 1. The m1 (Fig. 5E) has no basal cingulid at the labial or lingual side. A small entostylid is present at the posterolingual corner. The $\mathrm{m} 3$ (Fig. 5D) shows a protruding parastylid. Similarly to the lower molars found in Hayranl 1 , there is no trace of a labial cingulid.

Remarks. - Hitherto, eight different species of Desmanodon have been described: D. minor, D. major, D. antiquus, D. ziegleri, D. burkarti, D. daamsi, D. fluegeli and D. crocheti (Engesser 1980, Ziegler 1985, Van den Hoek Ostende 1997, Prieto 2010, Prieto et al. 2010). According to Doukas \& Van den Hoek Ostende (2006), the species D. meuleni must be considered a junior synonym of $D$. antiquus. As the remains of Desmanodon from Hayranlı 1 and Düzyayla do not fit the diagnostic descriptions for any of these eight forms, the definition of a new species is necessary. Unfortunately, the description of this new species does not include the humerus because this element has not been found.

\section{Biostratigraphy}

The exact age of Hayranlı 1 and Düzyayla is unknown. Ünay et al. (2003) ascribed Hayranlı 1 to local zone "J" (equivalent to the European biounits MN 11 and possibly also MN 10) and Düzyayla to local zone "K" (supposedly equivalent to the European MN 12). However, the present study does not show significant differences between both localities with respect to the insectivore assemblage. The only difference is the absence of Paenelimnoecus in Düzyayla, which can be explained by the small size of its elements combined with the wet-screening technique, which may result in an underestimation of this genus in continental series (Van den Hoek Ostende et al. 2009). Other than that, differences are minimal. Thus, from the point of view of the insectivore assemblages, both localities appear to be similar in age.

When trying to constrain the age (MN level) of our sites using the insectivore fauna, it can be noted that most species are not very helpful. For example, the entry of Schizogalerix sinapensis in Central Anatolia has a maximum age of $\sim 10.5 \mathrm{Ma}$, whereas the exit is associated with the transition from MN 12 to $\mathrm{MN} 13$ around $7 \mathrm{Ma}$ (Kappelman et al. 2003, Selänne 2003). The presence of Amblycoptus is potentially more informative. The oldest reported occurrences of Amblycoptus (A. oligodon) in Europe are from the Ukrainian localities Novoelizavetovka 2, Frunzovka 2 and Mikhailovka 2, which were ascribed to mammal unit MN 11 (Nesin \& Nadachowski 2001, Rzebik-Kowalska \& Nesin 2010; see also compilation in Van Dam 2004). However, this MN assignment has to be treated with care, because workers differ in the use of MN units, which are sometimes regarded as biostratigraphical units and sometimes as faunal units (Van Dam 2003). For instance, biostratigraphically used, Novoelizavetovka 2 should be assigned to MN 12, because of the presence of Parapodemus (or Apodemus) barbarae (Nesin \& Storch 2004), the entry of which has been used and proposed as the defining event for the base of MN 12 (Hilgen et al. 2012).

The size of Amblycoptus oligodon from Hayranl1 1 and Düzyayla is at the lower limit known for the genus Amblycoptus and its successor Kordosia. Although perhaps not belonging exactly to a single lineage (Mészáros 1997), species can be ordered to size as follows: A. oligodon - A. jessiae - K. topali. As Amblycoptus oligodon from Hayranlı 1 and Düzyayla is somewhat smaller than A. oligodon from other localities, it could be considered one of the oldest representatives of this species. On the other hand, geographical/latitudinal gradients may explain 

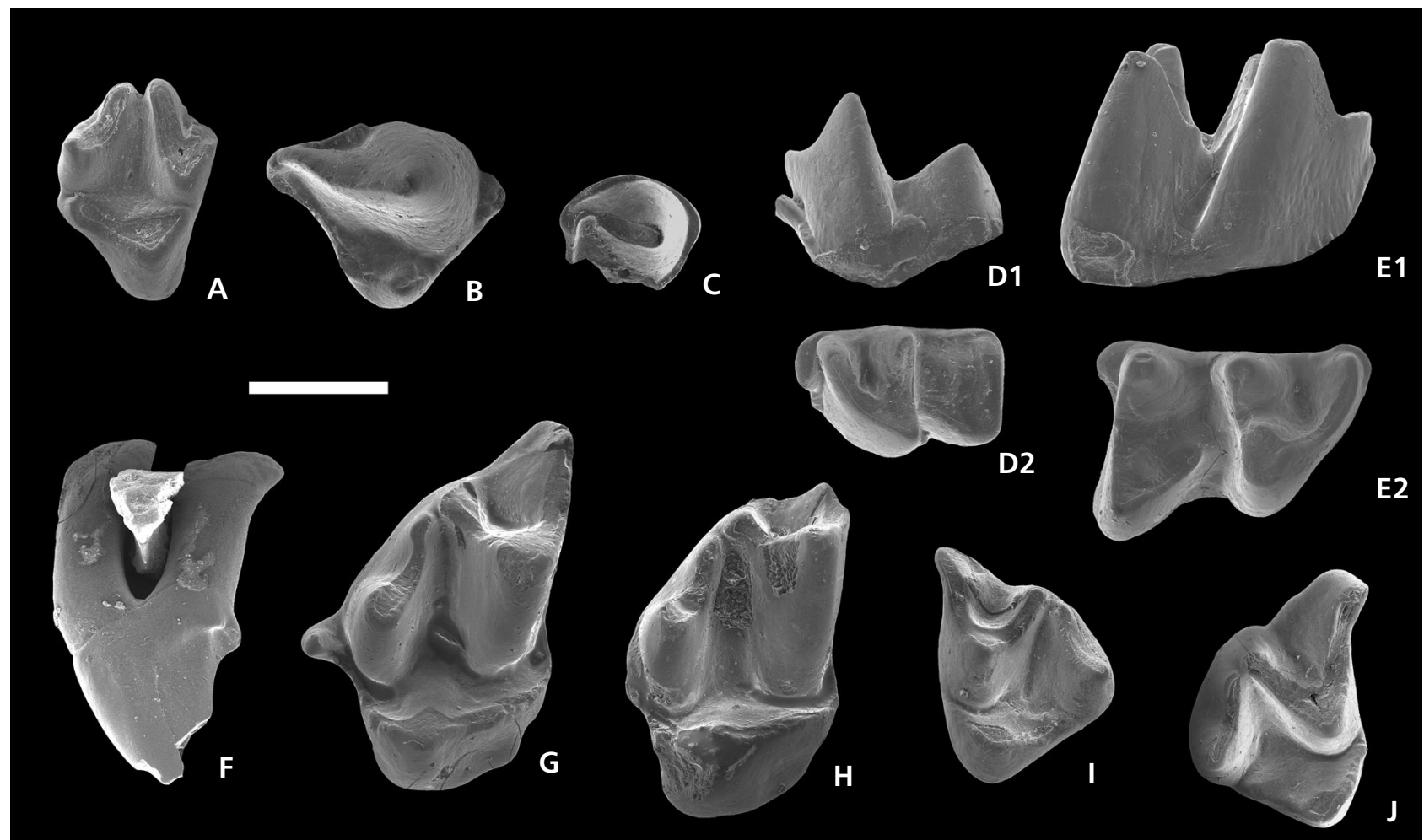

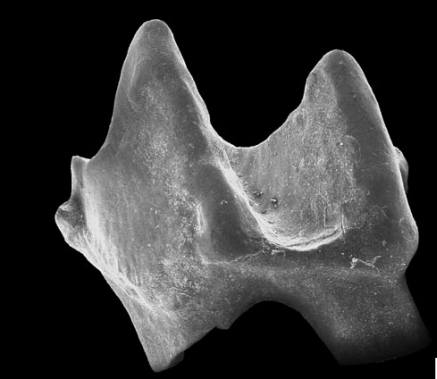

K1

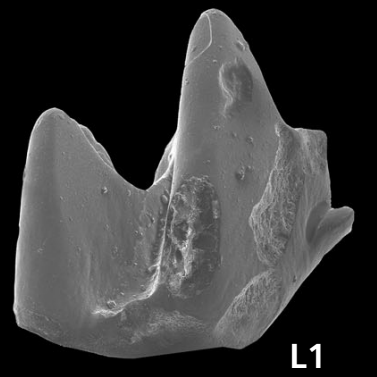

L1

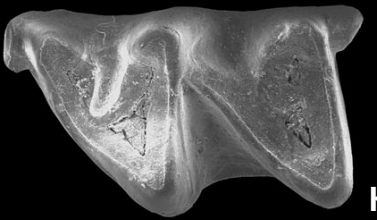

K2

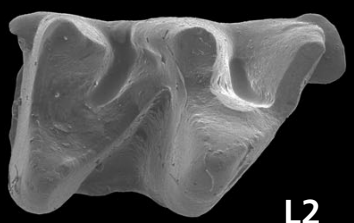

L2
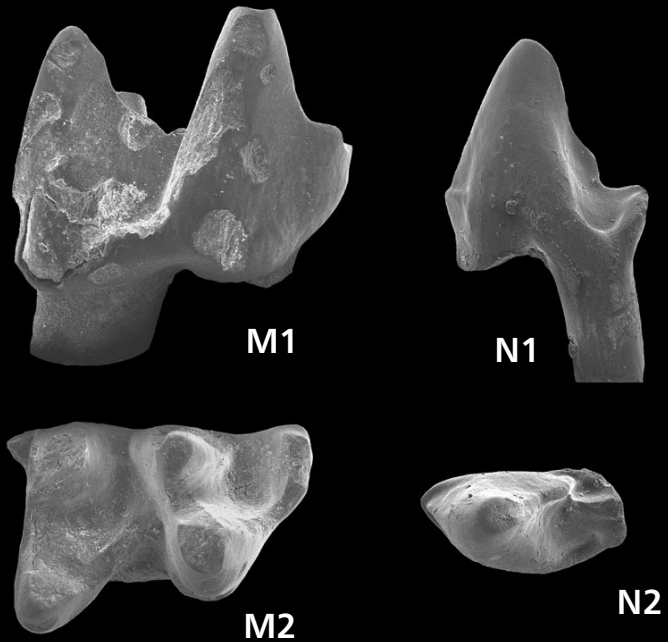

N2

Figure 5. Desmanodon larsi sp. nov. from Düzyayla (A-E) and Hayranlı 1 (F-N). • A - DÜ-1198 (right M3; occl. view); B - DÜ-1200 (right P4; occl. view); C - DÜ-1201 (right P3; occl. view); D - DÜ-1196 (left m3; 1 - lab. view; 2 - occl. view); E - DÜ-1154 (right m1; 1 - lab. view; 2 - occl. view); F - HAY1-858 (left C; lab. view); G - HAY1-849 (left M1; occl. view); H - HAY1-850 (left M1; occl. view); I - HAY1-852 (left M3; occl. view); J - HAY1-851 (right M3; occl. view); K - HAY1-857 (left m2; 1 - lab. view; 2 - occl. view); L - HAY1-854 (holotype; right m2; 1 - lab. view; 2 - occl. view); M - HAY1-856 (right m1; 1 - lab. view; 2 - occl. view); N - HAY1-853 (left p4; 1 - lab. view; 2 - occl. view). Scale bar equals 1 mm.

size differences as well. Another trend in AmblycoptusKordosia is the trend to merge the entoconid and the entostylid in the m1 (Doukas et al. 1995, Van Dam 2004). In this respect, the morphology of our Amblycoptus material also displays the most primitive condition, in which the entoconid is higher than the entostylid and both are strongly separated by a deep grove. In any case, the conclusion seems warranted that this form (at least the population of Düzyayla) is not expected to be younger than $A$. oligodon as occurring in various MN 12 (and MN 13) localities in Europe.

Petenyia dubia, originally described from the Austrian karstic locality of Kohfidisch (Bachmayer \& Wilson 1970), is a typical element in Turolian (MN 11-13) micromammalian assemblages. Its biostratigraphical range is partially obscured by some uncertainties on the taxonomy 
of the Blarinellini. The generic attribution of several species in this tribe (e.g., Petenyia dubia, Cokia robusta, Alloblarinella europaea) has changed in the last years, whereas many faunal lists have not been updated for decades. Nevertheless, according to the data compiled by Rzebik-Kowalska (1998), it seems quite evident that the heydays of $P$. dubia correspond to the Turolian, containing more than 90 per cent of the occurrences of this species or related forms. Earlier Vallesian finds (MN 9, Rudabánya and MN 10 Ambérieu 1) should be re-inspected to find out whether they truly correspond to this species or not.

The taxonomic identifications of the other insectivores described here do not allow for a more precise age determination. The genus Paenelimnoecus covers a very long time span along the Neogene, ranging from Early Miocene till Late Pliocene (Reumer 1992, Rzebik-Kowalska 1998, Storch et al. 1998). Its known range in Turkey thus far (MN 7-8) probably represents an underestimation of its real distribution, because of the small size of its elements and insufficient sampling. Paenelimnoecus from Hayranlı 1 could be considered as an intermediate form between Paenelimnoecus sp. 1 from Eskihisar and P. pannonicus from Csarnóta 2, but this possibility remains speculative. The scanty remains of Soricinae indet. and Crocidurinae/Crocidosoricinae indet. cannot be used for chronological inferences either, although it is worth noting that Engesser (1980) found a similar association of rare species in the Late Miocene locality of Kavurca (MN 13). Finally, Desmanella cingulata is limited to the Turkish locality of Eskihisar (MN 7-8). However, as in the case of Paenelimnoecus, its restricted distribution is probably due to the insufficient knowledge of the Anatolian Late Miocene continental record.

In summary, in terms of MN correlation our insectivore assemblages do not contradict earlier inferences based on rodents of a correlation of Düzyayla to $\mathrm{MN} 12$ by De Bruijn et al. (1999). Our observation that the insectivore faunas of Düzyayla and Hayranlı 1 appear virtually identical makes an assignment of the latter site to MN 12 feasible, although murine rodents (unpublished work) do indicate an older age for Hayranl1 1. When trying to explain this difference, it could also be suggested that Anatolian insectivores were subjected to very little evolutionary change during the Late Miocene. For the moment, we consider correlation of Hayranli 1 to both MN 11 and MN 12 possible.

An interesting consequence of the MN 11-12 assignment is the extension of the range of Desmanodon. Hitherto, the youngest occurrences of Desmanodon were limited to the late Middle Miocene (Engesser 1980, Van den Hoek Ostende 1997, Prieto et al. 2010). Desmanodon larsi sp. nov. is the largest species of the genus, with its size only comparable to that of $D$. major. According to Van den Hoek Ostende (1997), the lineage D. ziegleri - D. burkartiD. minor - D. major is characterized by a progressive in- crease in size, a gradual reduction of the protoconule and a widening of the mesostyle on the upper molars. Considering this trend, $D$. larsi sp. nov. is a likely descendant of $D$. major. The complete reduction of the labial cingulids in its lower molars also supports a more derived condition of D. larsi sp. nov. The presence of a P4 with "morphotype A" reinforces the link to $D$. major. Only the condition of the mesostyle (slightly split), is less consistent with such a direct descendence, because the separation of this cusps was thought to be more pronounced in the younger species. This could be indicating that the two species are not directly related, or that intraspecific variability is not entirely covered by our rather small samples.

The palaeoecological interpretation of the insectivore assemblages is beyond the scope of the present paper, and it will be part of a future overview paper also including the evidence based on rodents. However, a first approach on the palaeoenvironmental preferences of all the genera herein studied can be found in Furió et al. (2011).

\section{Summary}

The fossil insectivore assemblages from Hayranlı 1 and Düzyayla are almost identical, thus suggesting very similar ages for both sites.

The faunal list of insectivores includes Schizogalerix sinapensis, Paenelimnoecus sp., Amblycoptus oligodon, Petenyia dubia, Soricinae indet., Crocidurinae/Crocidosoricinae indet., Desmanella aff. cingulata and Desmanodon larsi sp. nov. All species have been recovered from both sites, except for Paenelimnoecus, which has not been found in Düzyayla.

The insectivore assemblage is typical for the Late Miocene. It points to an Early or Middle Turolian (MN 11-12) age, with a very small-sized $A$. oligodon as the most precise age indicator, excluding both MN 10 and MN 13. This is in agreement with the results from previous studies on fossil rodents, which indicated a similar age.

According to this interval constrain, D. larsi n.sp. is the youngest record of Desmanodon known up to now, and it extends significantly the previously known biostratigraphical range of this genus.

\section{Acknowledgements}

The collection trips to Hayranlı 1 and Düzyayla were financed by the Faculty of Earth Science of Utrecht University and by Hans de Bruijn. Furthermore, we acknowledge the support by the Netherlands Organization for Scientific Research and hospitality of the Faculty of Earth Science of Utrecht University (JvD), the Spanish Ministerio de Economía y Competitividad (Projects CGL2011-28681 and CGL2011-27343), as well as the AGAUR of the Generalitat de Catalunya (PIPH-2009 SGR 754). Field 
work and laboratory studies of F.K. were supported by the NSF-RHOI "Anatolian Upper Miocene Project" (Grant No. 0321893) and by the Academy of Finland by grant to Mikael Fortelius. We thank Hans de Bruijn, Albert van der Meulen and Gerçek Saraç and the Mineral Research and Exploration institute of Turkey (MTA) for collecting and supporting the sampling of Hayranlı 1 and Düzyayla. We are grateful to Hans de Bruijn for sorting and making available the material and commenting on the manuscript. Marta Palmero (ICP) is acknowledged for her drawings of Schizogalerix. The reviews carried out by Johannes Klietmann (University of Vienna) and Barbara Rzebik-Kowalska (Polish Academy of Sciences) improved the original version of this work.

\section{References}

BACHMAYER, F. \& WiLsON, R.W. 1970. Small mammals (Insectivora, Chiroptera, Lagomorpha, Rodentia) from the Kohfidisch Fissures of Burgenland, Austria. Annalen des Naturhistorischen Museums in Wien 74, 533-587.

Baudelot, S. 1972. Etude des Chiroptères, Insectivores et Rongeurs du Miocène de Sansan (Gers). 364 pp. Ph.D. thesis, Université de Toulouse, Tolouse, France.

BIBI, F. \& GÜLEÇ, E.S. 2008. Bovidae (Mammalia: Artiodactyla) from the Late Miocene of Sivas, Turkey. Journal of Vertebrate Paleontology 28(2), 501-519. DOI 10.1671/0272-4634(2008)28[501:BMAFTL]2.0.CO;2

Bosma, A.A., de Bruijn, H. \& Wessels, W. 2013. Late Miocene Sciuridae (Mammalia, Rodentia) from Anatolia, Turkey. Journal of Vertebrate Paleontology 33(4), 924-942. DOI 10.1080/02724634.2013.755990

De Bruijn, H., Mayda, S., Van den Hoek Ostende, L.W., KaYA, T. \& SARAÇ, G. 2006. Small mammals from the Early Miocene of Sabuncubeli (Manisa, S.W. Anatolia, Turkey). Beiträge zur Paläontologie 30, 57-87.

De Bruijn, H., Saraç, G., Van den Hoek Ostende, L.W. \& Roussiakis, S. 1999. The status of the genus name Parapodemus Schaub, 1938; new data bearing on an old controversy, 95-112. In Reumer, J.W.F. \& De Vos, J. (eds) Elephants have a snorkel! Papers in honour of Paul Y. Sondaar Deinsea 7.

De Bruijn, H., Ünay, E. \& HordiJK, K. 2013. A review of the Neogene succession of the Muridae and Dipodidae from Anatolia, with special reference to taxa known from Asia and/or Europe, 566-582. In WANG, X., FlynN, L.J. \& FoRTelius, M. (eds) Fossil Mammals of Asia. Neogene Biostratigraphy and Chronology. Columbia University Press, New York.

DiRIK, K., GöNCÜOĞLU, M.C. \& KozLu, H. 1999. Stratigraphy and pre-Miocene tectonic evolution of the southwestern part of the Sivas Basin, Central Anatolia. Geological Journal 34, 303-319.

DOI 10.1002/(SICI)1099-1034(199907/09)34:3<303::AID-GJ 829>3.0.CO;2-Z

Doukas, C.S. \& Vanden Hoek Ostende, L.W. 2006. Insectivores (Erinaceomorpha, Soricomorpha; Mammalia) from Karydia and Komotini (Thrace, Greece; MN 4/5). Beiträge zur Paläontologie 30, 109-131.

Doukas, C.S., Van den Hoek Ostende, L.W., Theocharopoulos, C.D. \& Reumer, J.W.F. 1995. The vertebrate locality Maramena (Macedonia, Greece) at the Turolian-Ruscinian Boundary (Neogene). Münchner Geowissenschaftliche Abhandlungen 28(A), 43-64.

ENGESSER, B. 1980. Insectivora und Chiroptera (Mammalia) aus dem Neogen der Türkei. Schweizerische Paläontologische Abhandlungen 102, 47-149.

Engesser, B. 2009. The Insectivores (Mammalia) from Sansan (Middle Miocene, south-western France). Schweizerische Paläontologische Abhandlungen 128, 1-95.

FURIó, M. 2007. Los Insectívoros (Soricomorpha, Erinaceomorpha, Mammalia) del Neógeno superior del Levante Ibérico. 299 pp. Ph.D. thesis, Universitat Autònoma de Barcelona, Barcelona, Spain.

Furió, M., Casanovas-Vilar, I. \& Van den Hoek Ostende, L.W. 2011. Predictable structure of Miocene insectivore (Lipotyphla) faunas in Western Europe along a latitudinal gradient. Palaeogeography, Palaeoclimatology, Palaeoecology 304, 219-229. DOI 10.1016/j.palaeo.2010.01.039

Furió, M., Santos-Cubedo, A., Minwer-Barakat, R. \& Agustí, J. 2007. Evolutionary history of the African soricid Myosorex (Insectivora, Mammalia) out of Africa. Journal of Vertebrate Paleontology 27(4), 1018-1032.

DOI 10.1671/0272-4634(2007)27[1018:EHOTAS]2.0.CO;2

García-Alix, A., Furió, M., Minwer-Barakat, R., MartínSuÁrez, E. \& Freudenthal, M. 2011. Environmental control on the distribution of Desmanella (Soricomorpha, Mammalia) in the Miocene of the Iberian Peninsula. Palaeontology 54(4), 753-762. DOI 10.1111/j.1475-4983.2011.01062.x

GiberT, J. 1975. New insectivores from the Miocene of Spain. Proceedings of the Koninklijke Nederlandse Akademie van Wetenschappen 78(2), 108-133.

Gibert, J. 1976. Nuevos datos sobre Crusafontina endemica. Acta Geológica Hispánica 11(2), 33-34.

Gürsoy, H., Piper, J.D.A., Tatar, O. \& Temiz, H. 1997. A palaeomagnetic study of the Sivas Basin, central Turkey: Crustal deformation during lateral extrusion of the Anatolian Block. Tectonophysics 271, 89-105.

DOI 10.1016/S0040-1951(96)00242-9

Hilgen, F.J., Lourens, L. \& van Dam, J.A. 2012. The Neogene Period, 947-1102. In Gradstein, F.M., OGG, J.G., SchmitZ, M.D. \& OGG, G. (eds) A geological time scale 2012. Elsevier, Amsterdam.

JANOSsy, D. 1972. Middle Pliocene microvertebrate fauna from Osztramos loc. 1 (Northern Hungary). Annales historico-naturales Musei nationalis hungarici 64, 27-52.

Jin, C.-Z. \& Kawamura, Y. 1997. A new species of the extinct shrew Paenelimnoecus from the Pliocene of Yinan, Shandong Province, northern China. Paleontological Research 1(1), $67-75$.

Kaya, F. \& KaymaKÇi, N. 2013. Systematics and dental microwear of the late Miocene Gliridae (Rodentia, Mammalia) from Hayranl, Anatolia: Implications for paleoecology and paleobiodiversity. Paleontologia Electronica 16(3), 21A, 1-22. 
Kappelman, J., Duncan, A., Feseha, M., Lunkka, J-P., Ekart, D., McDowell, F., Ryan, T.M. \& Swisher, C.C. 2003. Chronology, 41-66. In Fortelius, M., Kappelman, J., Sen, S. \& Bernor, R. (eds) Geology and Paleontology of the Miocene Sinap Formation, Turkey. Columbia University Press, New York.

Kormos, T. 1926. Amblycoptus oligodon n. g. und n. sp., eine neue Spitzmaus aus dem Ungarischen Pliozän. Annales historico-naturales Musei nationalis hungarici 24, 352-370.

Koufos, G.D. 2006. The Neogene mammal localities of Greece: Faunas, chronology and biostratigraphy. Hellenic Journal of Geosciences 41, 183-214.

MÉszÁros, L.G. 1996. Soricidae (Mammalia, Insectivora) remains from three Late Miocene localities in western Hungary. Annales Universitatis Scientarium Budapestinensis, Sectio Geologica 31, 5-25.

MészÁros, L.G. 1997. Kordosia, a new genus for some Late Miocene Amblycoptini shrews (Mammalia, Insectivora). Neues Jahrbuch für Geologie und Paläontologie, Monatshefte 1997(2), 65-78.

MÉsZÁros, L.G. 1998. Crusafontina (Mammalia, Soricidae) from Late Miocene localities in Hungary. Senckenbergiana lethaea 77(1/2), 145-159.

MészÁros, L.G. 1999. An exceptionally rich Soricidae (Mammalia) fauna from the upper Miocene localities of Polgárdi (Hungary). Annales Universitatis Scientiarium Budapestinensis, Sectio Geologica 32, 5-34.

Nesin, V.A. \& NadAchowski, A. 2001. Late Miocene and Pliocene small mammal faunas (Insectivora, Lagomorpha, Rodentia) of Southeastern Europe. Acta zoologica cracoviensia 44(2), 107-135.

Nesin, V.A. \& Storch, G. 2004. Neogene Murinae of Ukraine (Mammalia, Rodentia). Senckenbergiana lethaea 84, 351-365.

Prieto, J. 2010. The Middle Miocene mole Desmanodon crocheti sp. n. (Talpidae, Mammalia): the last representative of the genus in the North Alpine foreland basin. Paläontologische Zeitschrift 84(2), 217-225. DOI 10.1007/s12542-009-0038-0

Prieto, J., Gross, M., Böhmer, C. \& Böhme, M. 2010. Insectivores and bat (Mammalia) from the late Middle Miocene of Gratkorn (Austria): biostratigraphic and ecologic implications. Neues Jahrbuch für Geologie und Paläontologie, Abhandlungen 258(1), 107-119. DOI 10.1127/0077-7749/2010/0088

Reumer, J.W.F. 1984. Ruscinian and Early Pleistocene Soricidae frorn Tegelen (The Netherlands) and Hungary. Scripta Geologica $73,1-173$.

Reumer, J.W.F. 1992. The taxonomical position of the genus Paenelimnoecus Baudelot, 1972 (Mammalia: Soricidae): a resurrection of the subfamily Allosoricinae. Journal of Vertebrate Paleontology 12(1), 103-106. DOI 10.1080/02724634.1992.10011435

REumER, J.W.F. 1998. A classification of the fossil and recent shrews, 5-22. In WóJcik, J.M. \& Wolsan, M. (eds) Evolution of Shrews. Mammal Research Institute Polish Academy of Sciences, Białowieża.
Rzebik-Kowalska, B. 1975. The Pliocene and Pleistocene insectivores (Mammalia) of Poland. II. Soricidae: Paranourosorex and Amblycoptus. Acta zoologica cracoviensia 20(6), 167-182.

Rzebik-Kowalska, B. 1990a. Pliocene and Pleistocene Insectivora (Mammalia) of Poland. VI. Soricidae: Deinsdorfia Heller, 1963 and Zelceina Sulimski, 1962. Acta zoologica cracoviensia 33(4), 45-77.

RzebiK-Kowalska, B. 1990b. Pliocene and Pleistocene Insectivora (Mammalia) of Poland. VII. Soricidae: Mafia Reumer, 1984, Sulimskia Reumer, 1984 and Paenelimnoecus Baudelot, 1972. Acta zoologica cracoviensia 33(14), 303-327.

RzebiK-Kowalska, B. 1998. Fossil history of shrews in Europe, 23-92. In WóJciK, J.M. \& Wolsan, M. (eds) Evolution of Shrews. Mammal Research Institute Polish Academy of Sciences, Białowieża.

Rzebik-Kowalska, B. \& Nesin, V.A. 2010. Erinaceomorpha and Soricomorpha (Insectivora, Mammalia) from the Late Miocene of Ukraine. $61 \mathrm{pp}$. Institute of Systematics and Evolution of Animals, Polish Academy of Sciences, Krakow.

SELÄNNE, L. 2003. Genus Schizogalerix (Insectivora), 69-89. In Fortelius, M., Kappelman, J., Sen, S. \& Bernor, R. (eds) Geology and Paleontology of the Miocene Sinap Formation, Turkey. Columbia University Press, New York.

SEN, S. 1990. Stratigraphie, faunes de mammifères et magnétostratigraphie du Néogene de Sinap Tepe, Province d'Ankara, Turquie. Bulletin du Muséum National d'Histoire Naturelle 12(3-4), 243-277.

ȘEnGÖR, A.M.C. \& Yilmaz, Y. 1981. Tethyan evolution of Turkey: a plate tectonic approach. Tectonophysics 75, 181-241. DOI 10.1016/0040-1951(81)90275-4

Sickenberg, O., Becker-Platen, J.D., Benda, L., Berg, D., ENgesser, B., Gaziry, W., Heissig, K., Hunermann, K., SondaAr, P.Y., Schmidt-Kittler, N., Staesche, K., Staesche, U. \& STEFFEnS, P. 1975. Die Gliederung des höheren Jungtertiärs und Altquartiärs in der Türkei nach Vertebraten und ihre Bedeutung fur die International Neogen-stratigraphie. Geologisches Jahrbuch B15, 1-167.

Storch, G. 1995. The Neogene mammalian faunas of Ertemte and Harr Obo in Inner Mongolia (Nei Mongol), China. 11. Soricidae (Insectivora). Senckenbergiana lethaea 75(1/2), 221-251.

Storch, G., Qiu, Z., \& ZAZhigin, V.S. 1998. Fossil history of shrews in Asia, 93-120. In Wó JCiк, J.M. \& Wolsan, M. (eds) Evolution of Shrews. Mammal Research Institute Polish Academy of Sciences, Białowieża.

Sulimski, A., Szynkiewicz, A. \& Woloszyn, B. 1979. The Middle Pliocene Micromammals from Central Poland. Acta Palaeontologica Polonica 24(3), 377-403.

Ünay, E., De Bruijn, H. \& Saraç, G. 2003. A preliminary zonation of the continental Neogene of Anatolia based on rodents, 539-547. In Reumer, J.W.F. \& Wessels, W. (eds) Distribution and Migration of Tertiary Mammals in Eurasia. A volume in Honour of Hans de Bruijn. Deinsea 10.

VAN DAM, J.A. 2003. European Neogene mammal chronology: past, present and future, 85-95. In REUMER, J.W.F. \& WESSELS, W. (eds) Distribution and Migration of Tertiary Mam- 
mals in Eurasia. A volume in Honour of Hans de Bruijn. Deinsea 10.

VAN DAM, J.A. 2004. Anourosoricini (Mammalia: Soricidae) from the Mediterranean region: a pre-Quaternary example of recurrent climate-controlled north-south range shifting. Journal of Paleontology 78(4), 741-764.

DOI 10.1666/0022-3360(2004)078<0741:AMSFTM >2.0.CO;2

VAn DEN Hoek Ostende, L.W. 1997. Insectivore faunas from the Lower Miocene of Anatolia. Part 4: The genus Desmanodon (Talpidae) with the description of a new species from the Lower Miocene of Spain. Proceedings of the Koninklijke Nederlandse Akademie van Wetenschappen 100(1-2), $27-65$.

Van den Hoek Ostende, L.W., Furió, M. \& García-Paredes, I. 2009. New data on Paenelimnoecus from the middle Miocene of Spain support the shrew subfamily Allosoricinae. Acta
Palaeontologica Polonica 54(1), 159-164.

DOI 10.4202/app.2009.0117

VAN DER MADE, J. 1996. Pre-Pleistocene land mammals from Crete, 69-79. In ReESe, D.S. (ed.) Pleistocene and Holocene fauna of Crete and its first settlers. Monographs in World Archaeology 28.

VAn der Made, J., Güleç, E. \& ERKman, C. 2013. Microstonyx (Suidae, Artiodactyla) from the Upper Miocene of Hayranl1Haliminhan1, Turkey. Turkish Journal of Zoology 37, 106-122.

ZIEGLER, R. 1985. Talpiden (Mammalia, Insectivora) aus dem Orleanium und Astaracium Bayerns. Mitteilungen der Bayerische Staatssammlung für Paläontologie und Historische Geologie 25, 131-175.

ZIEGLER, R. 2005. The insectivores (Erinaceomorpha and Soricomorpha, Mammalia) from the Late Miocene hominoid locality Rudabánya. Palaeontographia Italica 90, 53-81. 